\title{
Immunomodulatory Effects of Hydroxychloroquine and Chloroquine in Viral Infections and Their Potential Application in Retinal Gene Therapy
}

\author{
Laurel C. Chandler ${ }^{1,2, * \mathbb{D}}$, Imran H. Yusuf ${ }^{1,2} \mathbb{D}$, Michelle E. McClements ${ }^{1} \mathbb{D}$, Alun R. Barnard ${ }^{1,2}$, \\ Robert E. MacLaren ${ }^{1,2}$ and Kanmin Xue $1,2, *$ D \\ 1 Nuffield Laboratory of Ophthalmology, Nuffield Department of Clinical Neurosciences \& NIHR Oxford \\ Biomedical Research Centre, University of Oxford, Oxford OX3 9DU, UK \\ 2 Oxford Eye Hospital, Oxford University Hospitals NHS Foundation Trust, Oxford OX3 9DU, UK \\ * Correspondence: laurel.chandler@merton.ox.ac.uk (L.C.C.); kanmin.xue@eye.ox.ac.uk (K.X.)
}

Received: 6 June 2020; Accepted: 9 July 2020; Published: 14 July 2020

\begin{abstract}
Effective treatment of retinal diseases with adeno-associated virus (AAV)-mediated gene therapy is highly dependent on the proportion of successfully transduced cells. However, due to inflammatory reactions at high vector doses, adjunctive treatment may be necessary to enhance the therapeutic outcome. Hydroxychloroquine and chloroquine are anti-malarial drugs that have been successfully used in the treatment of autoimmune diseases. Evidence suggests that at high concentrations, hydroxychloroquine and chloroquine can impact viral infection and replication by increasing endosomal and lysosomal $\mathrm{pH}$. This effect has led to investigations into the potential benefits of these drugs in the treatment of viral infections, including human immunodeficiency virus and severe acute respiratory syndrome coronavirus-2. However, at lower concentrations, hydroxychloroquine and chloroquine appear to exert immunomodulatory effects by inhibiting nucleic acid sensors, including toll-like receptor 9 and cyclic GMP-AMP synthase. This dose-dependent effect on their mechanism of action supports observations of increased viral infections associated with lower drug doses. In this review, we explore the immunomodulatory activity of hydroxychloroquine and chloroquine, their impact on viral infections, and their potential to improve the efficacy and safety of retinal gene therapy by reducing AAV-induced immune responses. The safety and practicalities of delivering hydroxychloroquine into the retina will also be discussed.
\end{abstract}

Keywords: hydroxychloroquine; chloroquine; adeno-associated virus; AAV; gene therapy; innate immunity; TLR9; cGAS; SARS-CoV-2

\section{Introduction}

The 4-aminoquinoline anti-malarial drugs, hydroxychloroquine and chloroquine, have been frequently used in the treatment of autoimmune diseases such as systemic lupus erythematosus and rheumatoid arthritis. Their utility in dampening these autoimmune diseases provides insights into their immunomodulatory activities [1]. Hydroxychloroquine and chloroquine are weak bases that accumulate within acidic intracellular compartments, such as lysosomes [2]. When used at high concentrations, hydroxychloroquine and chloroquine appear to lead to a dose-dependent increase in endosomal and lysosomal $\mathrm{pH}[3,4]$. In contrast, low concentrations of hydroxychloroquine and chloroquine may exert a separate immunomodulatory effect on intracellular innate immune responses to viral infections, with minimal interference in lysosomal activity $[5,6]$.

Adeno-associated viruses (AAV) are the most commonly used viral vectors for gene therapy due to their broad tissue tropism, relatively low immunogenicity, and lack of pathogenicity. 
$\mathrm{AAV}$ are non-replicating, non-enveloped parvoviruses with a single-stranded DNA (ssDNA) genome. A recombinant AAV transgene typically contains a therapeutic gene expression cassette driven by a ubiquitous or tissue-specific promoter with a generic polyadenylation signal. The cassette is flanked by viral inverted terminal repeats (ITRs), which aid persistence through the formation of concatemeric episomes within the host cell nucleus [7]. The episomes can sustain long-term transgene expression while minimising the potential for mutagenesis. Nonetheless, AAV-specific immune responses have been observed, which may induce potentially harmful inflammatory reactions and compromise the outcome of gene therapy [8].

AAV-mediated gene therapies have been successfully applied to a number of monogenic retinal dystrophies, including RPE65-associated Leber congenital amaurosis which has received Food and Drug Administration (FDA) approval, and choroideremia and RPGR-associated X-linked retinitis pigmentosa which are in advanced clinical trials [9-14]. Despite promising results in clinical trials, dose-dependent immunogenicity of $\mathrm{AAV}$ has been observed following retinal gene therapy, requiring high-dose immunosuppression in some cases [14-17]. There is thus interest in adjuvant therapies, either local or systemic, to reduce inflammatory responses and improve the long-term durability of gene therapies.

In this review, we discuss the immunomodulatory effects of hydroxychloroquine and chloroquine and how these might be relevant in the treatment of viral infections. We will then discuss how hydroxychloroquine might be used to control immune responses to AAV and enhance the efficacy of gene therapy.

\section{Immunomodulatory Mechanisms of Hydroxychloroquine and Chloroquine}

Hydroxychloroquine and chloroquine have been used for many decades in the treatment of a wide range of infections, including malaria (prozozoal), $Q$ fever (bacterial), and human immunodeficiency virus (HIV) (viral), and autoimmune diseases such as systemic lupus erythematosus and rheumatoid arthritis [18]. Despite the proposal of numerous putative modes of action involving interactions with a range of molecular targets and signalling pathways, the immunomodulatory effects of hydroxychloroquine and chloroquine remain uncertain.

\subsection{Effects on Intracellular Innate Immune Responses}

A major advance in the effort to understand the mechanism of action of hydroxychloroquine and chloroquine was the discovery of their antagonistic effects on members of the toll-like receptor (TLR) family, a group of pattern recognition receptors (PRRs) that can detect molecular signatures of pathogens, such as bacteria and viruses, in order to elicit rapid intracellular immune responses [19]. Within this family, TLR3, TLR7, TLR8, and TLR9 are nucleic acid sensors that are exclusively found within endosomes so to minimise exposure to self-DNA or-RNA [20]. TLR3 detects double-stranded RNA (dsRNA) [21], TLR7 and TLR8 recognise single-stranded RNA (ssRNA) [22], and TLR9 is activated by DNA containing unmethylated CpGs which are abundant in microbial but rare in vertebrate genomes (i.e., $60-90 \%$ of mammalian CpGs are methylated) [23,24]. These nucleic acid ligands are also common features of viral genomes, thus TLRs play an important role in the detection of viruses within cells as part of the innate immune defence against viral infections. Initial in vitro studies demonstrated that chloroquine could suppress the stimulatory activity of CpG-oligodeoxynucleotides (ODNs) at concentrations $\leq 10 \mu \mathrm{M}$, thereby inhibiting cytokine release [5,25]. Subsequent studies demonstrated the dose-dependent inhibition of CpG-ODN binding to TLR9 by $\leq 2.5 \mu \mathrm{M}$ chloroquine in human embryonic kidney 293 (HEK293) cells [26] (Figure 1). Although this interaction was optimal in acidic endosomal environments at pH 5.5-6.5 [26], TLR9 inhibition can be achieved with significantly lower concentrations of chloroquine than that needed to alter the $\mathrm{pH}$ of endosomal compartments $(\leq 20 \mu \mathrm{M})[4-6]$. Based on these findings, it was proposed that hydroxychloroquine and chloroquine could bind to $\mathrm{CpG}$-containing nucleic acids and induce conformational changes that prevent them from interacting with and activating TLR9 [6,27]. Furthermore, chloroquine inhibited ssRNA-mediated 
TLR8 activation and poly(I:C) (synthetic analogue of dsRNA)-mediated TLR3 activation in HEK293 cells in a dose-dependent manner $(\leq 20 \mu \mathrm{M})$ [6]. In human monocyte-derived dendritic cells and peripheral blood mononuclear cells (PBMCs), chloroquine inhibited poly(I:C)-induced TLR3 responses at concentrations $\leq 10 \mu \mathrm{M}$ [28]. Chloroquine has also been shown to inhibit TLR7-mediated responses to small nuclear ssRNA in human PBMCs at a concentration $\leq 10 \mu \mathrm{M}$, resulting in the downregulation of IFN- $\alpha$ expression [29] (Figure 1).

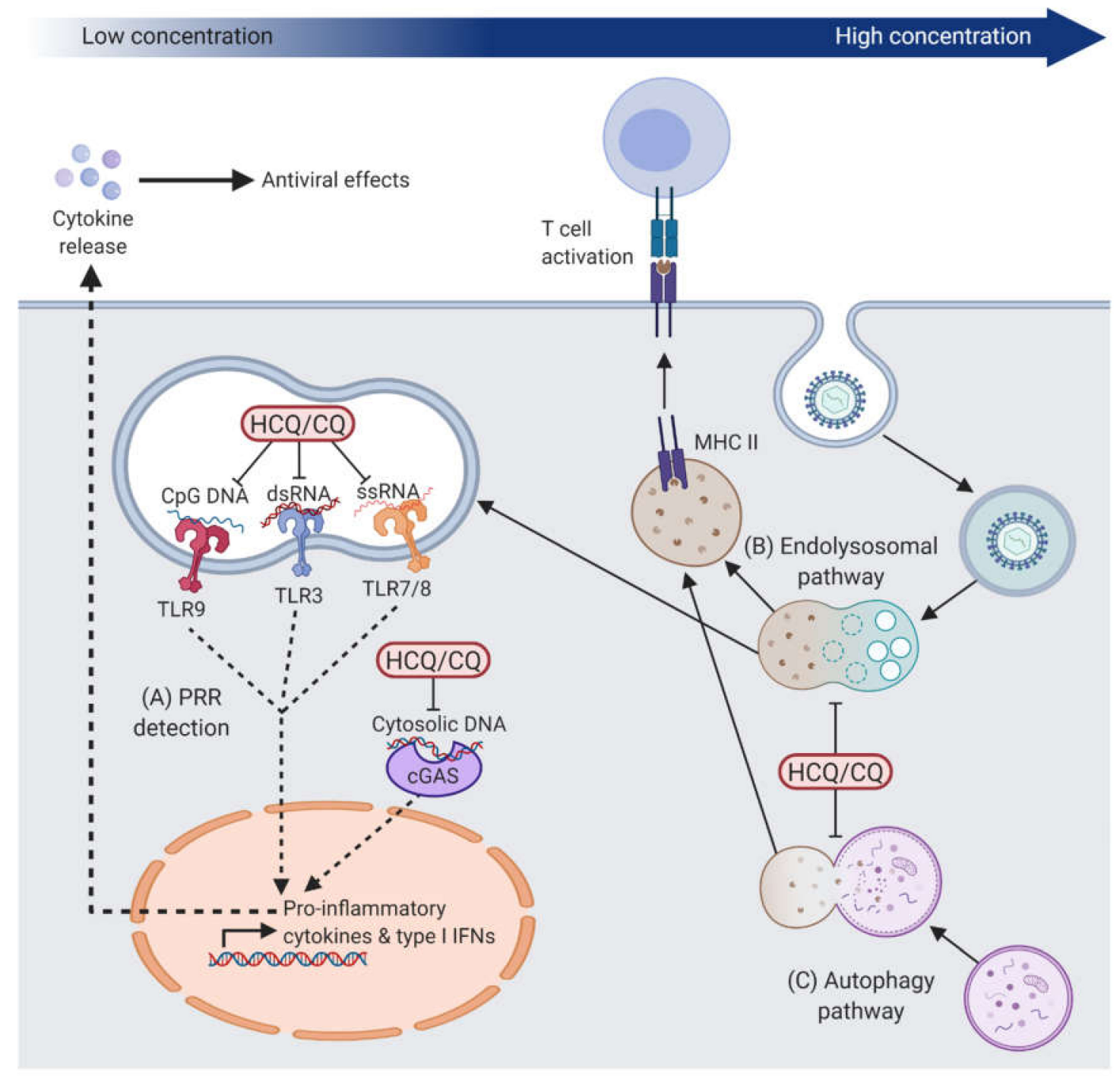

Figure 1. Immunomodulatory mechanisms of hydroxychloroquine (HCQ) and chloroquine (CQ). (A) At lower concentrations, which we define as $\leq 20 \mu \mathrm{M}, \mathrm{HCQ}$ and CQ can inhibit the activation of nucleic acid sensors, Toll-like receptors (TLR) in endosomes and cyclic GMP-AMP synthase (cGAS) in the cytoplasm. This leads to the inhibition of pattern recognition receptor (PRR)-induced activation of downstream pro-inflammatory cytokine and type I interferon (IFN) gene expression. At high concentrations $(\geq 100 \mu \mathrm{M}), \mathrm{HCQ}$ and CQ can increase lysosomal $\mathrm{pH}$, which leads to disruption of presentation of (B) extracellular antigens processed through the endolysosomal pathway and (C) intracellular antigens processed through the autophagosome-lysosome fusion pathway by antigen presenting cells. dsRNA, double-stranded RNA; ssRNA; single-stranded RNA; MHC II, major histocompatibility complex class II.

In addition to the inhibition of TLRs, hydroxychloroquine has been shown to have an inhibitory effect on the PRR cyclic GMP-AMP synthase (cGAS). cGAS is activated by cytosolic DNA, which is 
indicative of viral infection, to initiate a signalling cascade leading to a type I interferon response [30,31]. An in silico screen of drug libraries to find cGAS antagonists identified several antimalarial drugs as putative inhibitors and further computational analysis predicted an interaction between hydroxychloroquine and the DNA binding site of cGAS [32]. Following dsDNA transfection of the human monocytic cell line (THP1), hydroxychloroquine treatment decreased expression of interferon (IFN)- $\beta$, a downstream cytokine of cGAS activation, in a dose-dependent manner with a half-maximal inhibitory concentration (IC50) of $25 \mu \mathrm{M}$ [32] (Figure 1). It remains unclear whether the inhibitory effect of hydroxychloroquine on cGAS is achieved through hydroxychloroquine binding to cGAS or the DNA. Nonetheless, given the proposed mechanism of action via TLR9, it seems possible that hydroxychloroquine and chloroquine might prevent the activation of nucleic acid sensors cGAS and TLR9 through a common mechanism such as alteration of the structural configuration of the DNA substrate [33,34].

These findings have gone some way to explain the efficacy of hydroxychloroquine and chloroquine in the treatment of systemic lupus erythematosus and rheumatoid arthritis. A hallmark of both autoimmune diseases is the accumulation of DNA- or RNA-containing complexes due to a build-up of apoptotic bodies, which have been implicated in the activation of TLR9 or TLR7, respectively [35,36]. Recent studies in patient-derived PBMCs have suggested that cGAS may also be important in the detection of DNA in systemic lupus erythematosus [37,38]. Indeed, redundancy and overlap between the substrates of different nucleic acid sensors seem likely and evolutionarily advantageous. In preventing the activation of these PRRs, hydroxychloroquine or chloroquine may be able to dampen an overactive innate immune response to self-nucleic acids in systemic lupus erythematosus and rheumatoid arthritis. The same mechanism would also enable hydroxychloroquine and chloroquine to reduce the immune response to foreign nucleic acid antigens, such as those derived from viral infections.

\subsection{Effects on Cellular Immune Responses}

The inhibition of key PRRs, such as TLR9 and cGAS, by hydroxychloroquine and chloroquine has been shown to affect downstream pro-inflammatory cytokine and type I interferon responses (Figure 2) $[6,29,32]$. In vitro, both hydroxychloroquine and chloroquine have been shown to inhibit the production of the pro-inflammatory cytokines tumour necrosis factor- $\alpha$ (TNF- $\alpha$ ), IFN- $\gamma$ and interleukin (IL)-6 in PBMCs [39], and TNF- $\alpha$, IL-1 $\beta$, and IL-6 in human monocytes [40]. IFN- $\gamma$ can prime macrophages for pro-inflammatory responses and render them resistant to suppressive immune factors [41]; IL-6 can control the survival, expansion, and maturation of B cells [42]; and TNF $\alpha$ is key in activating and promoting the long-term survival of macrophages [43]. Chloroquine has also been demonstrated to inhibit c-Jun N-terminal kinase (JNK)-mediated activation of the transcription factor activator protein 1 (AP-1) in $\mathrm{CD}^{+} \mathrm{T}$ cells [44]. The resulting reduction in helper $\mathrm{T}$ cell activation, proliferation, and cytokine release would be expected to reduce the level of immune response. A type I interferon response also induces an anti-viral state within the infected and neighbouring cells by upregulating a large number of interferon-stimulated genes (ISGs) via the Janus kinase-signal transducer and activator of transcription (JAK-STAT) pathway [45]. Examples include tripartite motif-containing $5 \alpha$ (TRIM5 $\alpha$ ) that can bind to viral capsid proteins to promote viral disassembly and restrict infection [45]; ISG15 which is a ubiquitin-like protein that can covalently bind to viral proteins to disrupt replication [46]; and IL-15 that helps to eliminate infected cells by inducing the proliferation and maintenance of natural killer cells and $\mathrm{CD} 8^{+} \mathrm{T}$ cells $[47,48]$. 


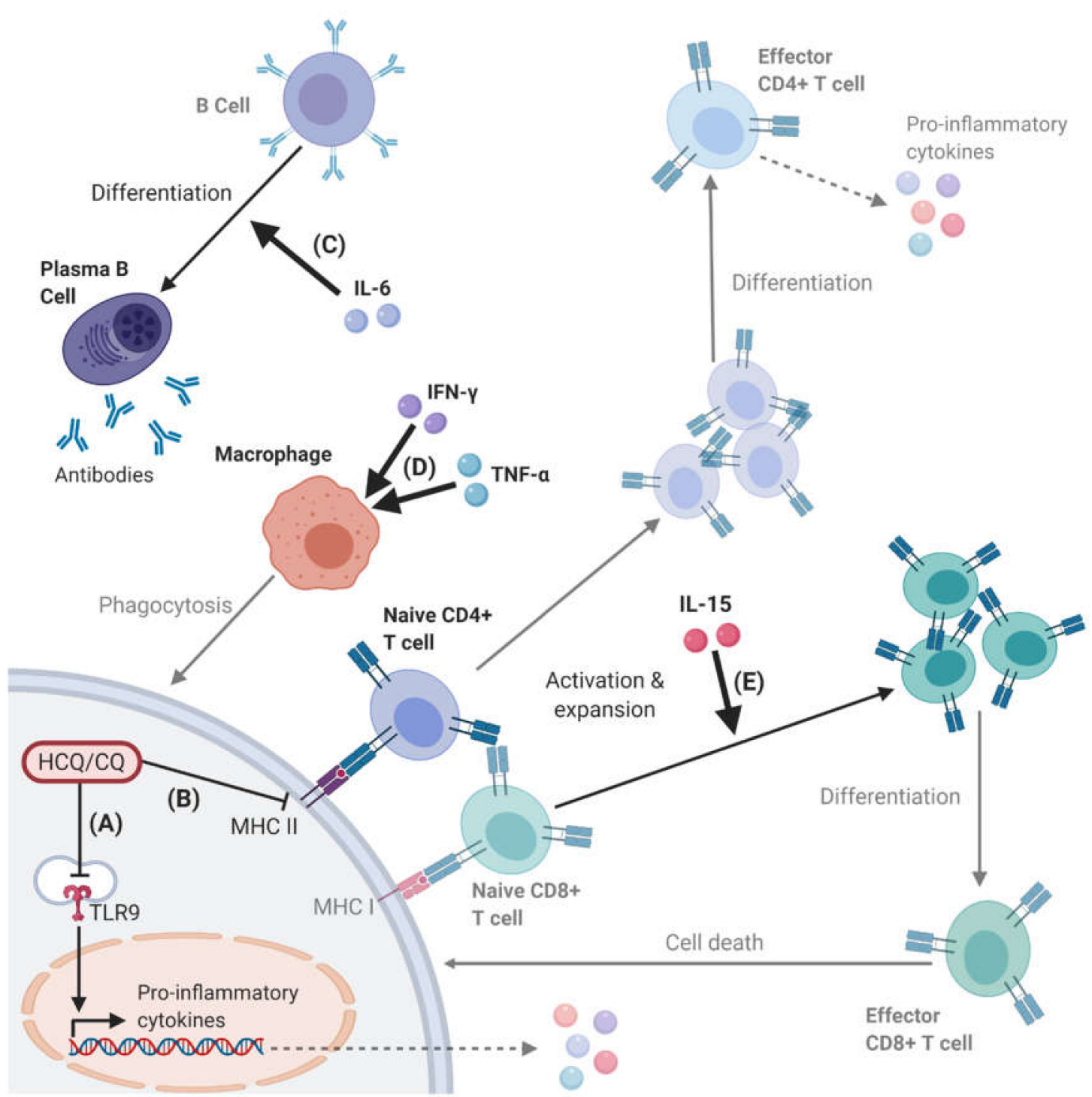

Figure 2. Effects of pro-inflammatory cytokines on cell-mediated immune responses. An example of cell-mediated immune responses downstream of the immunomodulatory effects of HCQ and CQ. HCQ and CQ can reduce pro-inflammatory cytokine expression by inhibition of (A) PRRs (e.g., TLR9) at low concentrations or (B) MHC II-mediated antigen presentation at high concentrations (see Figure 1). MHC II can activate CD4 ${ }^{+} \mathrm{T}$ cells, which are another major source of pro-inflammatory cytokines. Key pro-inflammatory cytokines include (C) interleukin (IL)- 6 that can stimulate the maturation and expansion of B cells into antibody-producing plasma cells, (D) IFN- $\gamma$ and tumour necrosis factor- $\alpha$ (TNF- $\alpha$ ) that can activate macrophages, and (E) IL-15 that can stimulate the activation and expansion of $\mathrm{CD}^{+} \mathrm{T}$ cells. Lower opacity text and images represent the indirect effects, while those in bold highlight the direct effects of HCQ, CQ, and pro-inflammatory cytokines.

In addition to the inhibition of PRRs and their downstream signalling cascades, hydroxychloroquine and chloroquine also appear capable of indirectly modulating immune responses though the alkalisation of lysosomes when used at higher concentrations. The processing of extracellular material for antigen presentation is classically undertaken by professional antigen-presenting cells, which utilise the lysosomal pathway to display short peptides on major histocompatibility complex (MHC) class II molecules for detection by $\mathrm{CD}^{+} \mathrm{T}$ cells [49]. By increasing the $\mathrm{pH}$ of lysosomes, chloroquine can affect antigen processing, as demonstrated in macrophages (at $100 \mu \mathrm{M}$ ) [50], dendritic cells (at $100 \mu \mathrm{M}$ ) [51] and B cells (at 25-100 $\mu \mathrm{M}$ ) [52]. Notably, these effects, which are 
associated with raised endosomal and lysosomal $\mathrm{pH}$, were primarily observed at high concentrations of chloroquine $(100 \mu \mathrm{M})$. In addition, chloroquine has been shown to inhibit autophagy, a regulated process for removing damaged intracellular organelles or proteins by enveloping cytoplasmic material, by inhibiting the fusion between autophagosomes and lysosomes [53]. This, in turn, leads to the inhibition of presentation of cytosolic antigens, including autoantigens and viral antigens, on MHC class II molecules via the autophagy-lysosomal pathway [54-56] (Figure 1). Since dysregulation of autophagy contributes to cancer development and chemotherapy resistance, hydroxychloroquine has been evaluated as an autophagy inhibitor in clinical trials for various cancers [57-60]. Very high daily doses of hydroxychloroquine (typically $\leq 1200 \mathrm{mg} /$ day) have been used in this context in order to effectively block the fusion of lysosomes with autophagosomes, thus supporting a dose-dependent mechanism of action of hydroxychloroquine. Overall, study findings are consistent with hydroxychloroquine and chloroquine having a direct immunosuppressive effect on viral sensing and pro-inflammatory cytokine release at low concentrations, and an indirect immunomodulatory effect via lysosomal antigen processing and presentation at high concentrations (Figure 1).

\section{Effects of Hydroxychloroquine and Chloroquine on Viral Infections}

Historically, hydroxychloroquine and chloroquine have been utilised as tools to assess the effect of endosomal and lysosomal processes on viral entry, as many viruses exploit the host endocytic machinery to infect target cells. Following cell surface receptor binding, viral particles are internalised via a range of endocytic mechanisms, including clathrin-mediated, caveolin-mediated, and non-clathrin non-caveolin endocytosis. Endosomes undergo gradual acidification from an early to late stage, which acts as a trigger for viral uncoating and genome release so that endosomal escape is precisely timed to prevent overexposure of viral contents to the acidic environment [61]. The inhibition of replication of Semliki Forest virus [62], Chikungunya virus [63], and hepatitis A virus [64] by chloroquine in vitro has been suggested to occur as a result of impaired endosomal acidification and viral entry due to the concentration of this drug in intracellular compartments. In addition, the acidification of vesicular compartments along the secretory pathway is important in the post-translational modification of viral envelope proteins during the production of new infectious virions. For example, in vitro studies demonstrated that hydroxychloroquine and chloroquine could inhibit the production of infectious HIV-1 virions by preventing glycosylation of the viral glycoprotein gp120, which normally occurs within the acidic Golgi complex [65-67]. In addition, chloroquine treatment resulted in the accumulation of non-infectious herpes simplex virus (HSV)-1 virions in the trans-Golgi network in vitro [68]. Taken together, these observations support the potential anti-viral effects of hydroxychloroquine and chloroquine in vitro when used at sufficient concentrations to alter endosomal $\mathrm{pH}$, but in vivo efficacy remains unclear.

\subsection{Immunomodulatory Effects on Viral Infections}

The combination of the alkalisation of the endolysosomal pathway and the immunomodulatory effects of hydroxychloroquine and chloroquine have led to speculations surrounding their potential benefits in the treatment of viral infections. Although both innate and adaptive immune responses are vital to recovery from viral infections, over activation of immune responses may lead to harmful tissue damage and disease progression. Such counterproductive immune responses have been observed in chronic HIV [69], severe acute respiratory syndrome coronavirus (SARS-CoV) [70], and SARS-CoV-2 infections [71], leading to investigation of hydroxychloroquine and chloroquine as potential immunomodulatory therapies. Systemic T cell activation in chronic HIV infection is thought to be associated with disease progression. A randomised controlled trial showed that chloroquine therapy could reduce the proportion of CD38 ${ }^{+}$HLA-DR ${ }^{+}$CD8 T cells, thus supporting its usage in certain groups of HIV patients [72]. The effect may be explained by chloroquine-mediated suppression of TLR7 activation by HIV RNA in primary monocytes and plasmacytoid dendritic cells (pDCs) [73-75]. Similarly, in vitro chloroquine has been shown to prevent TLR7-mediated responses to 
other RNA viruses such as hepatitis C [76,77], influenza [78] and vesicular somatic virus [79], as well as TLR9-mediated responses to DNA viruses such as HSV-2 and Epstein-Barr virus [80-82]. There appears to be a general correlation between the concentration of chloroquine or hydroxychloroquine used and the effects seen in vitro (Table 1). High doses of these drugs, which we define as $\geq 100 \mu \mathrm{M}$, tend to inhibit viral replication, while low doses $(\leq 20 \mu \mathrm{M})$ tend to inhibit innate immune pathways without detectable effect on viral replication. This correlation is consistent with the hypothesis that high concentrations of hydroxychloroquine or chloroquine could inhibit viral entry or assembly by increasing the $\mathrm{pH}$ of intracellular vesicular compartments, while low concentrations could reduce pro-inflammatory cytokine release by preventing the activation of nucleic acid sensors. Nonetheless, a degree of overlap could be expected between these two types of effects, which may be variable between different cell lines. Of note, Vero cells derived from the kidney epithelium of the African green monkey, which are commonly used to propagate viruses in vitro, harbour a $9 \mathrm{Mb}$ deletion leading to loss of the type I interferon gene cluster $[83,84]$. Therefore, Vero cells would not be an appropriate model for assessing the immunomodulatory effects of these drugs during viral infection. Further work is needed to assess the effects of hydroxychloroquine and chloroquine on viral infection in biologically relevant cell types and in vivo.

Table 1. Effects of hydroxychloroquine and chloroquine on selected viruses in vitro.

\begin{tabular}{|c|c|c|c|c|c|c|}
\hline Effect & Drug & Concentration $(\mu \mathrm{M})$ & Virus & Viral Genome & Cells & Reference \\
\hline \multirow{6}{*}{ Inhibition of viral replication ${ }^{1}$} & \multirow{5}{*}{ CQ } & 75 & Yellow fever virus & ssRNA & P388D1 & {$[85]$} \\
\hline & & 100 & Semliki Forest virus & ssRNA & BHK-21 & [62] \\
\hline & & $10-100$ & Hepatitis A virus & ssRNA & BS-C-1 & [64] \\
\hline & & 150 & HSV-1 & dsDNA & $\mathrm{HuH7}$ & [68] \\
\hline & & $250-4000$ & Varicella zoster virus & dsDNA & Mononuclear cells & [86] \\
\hline & HCQ & $1-1000$ & HIV-1 & ssRNA & $\begin{array}{l}\mathrm{T} \text { cell and macrophage } \\
\text { hybridoma cell line }\end{array}$ & [67] \\
\hline \multirow{6}{*}{$\begin{array}{l}\text { Inhibition of virus-mediated } \\
\text { immune response }{ }^{1}\end{array}$} & \multirow{5}{*}{ CQ } & 10 and 100 & Hepatitis $\mathrm{C}$ virus & ssRNA & Huh7 and macrophages & {$[76,77]$} \\
\hline & & 10 & HSV-2 & dsDNA & $\mathrm{pDCs}$ & {$[80]$} \\
\hline & & $1-100$ & Vesicular stomatitis virus & ssRNA & $\mathrm{pDCs}$ & [79] \\
\hline & & 10 & Influenza A virus & ssRNA & $\mathrm{pDCs}$ & [78] \\
\hline & & 5 and 100 & HIV-1 & ssRNA & pDCs and PBMCs & {$[73,74]$} \\
\hline & HCQ & 10 and 20 & Epstein Barr virus & dsDNA & pDCs and monocytes & {$[81,82]$} \\
\hline
\end{tabular}

${ }^{1}$ In vitro studies conducted in Vero cells were excluded because of the inability for these cells to produce type I interferon responses, making them unsuitable for assessing the immunomodulatory effects of HCQ and CQ. HSV, herpes simplex virus; $\mathrm{pDC}$, plasmacytoid dendritic cell; HIV, human immunodeficiency virus.

In contrast to their inhibitory effects on viral replication in vitro, hydroxychloroquine and chloroquine may have different effects in vivo due to the lower systemic concentrations achieved and their inhibitory effects on anti-viral responses, such as those mediated through TLRs. In a randomised, double-blind, controlled trial of $400 \mathrm{mg} /$ day of hydroxychloroquine versus placebo in patients with asymptomatic HIV infection and not on anti-retroviral therapy, hydroxychloroquine was found to be associated with an increased HIV viral RNA load as well as a faster decline in $\mathrm{CD}^{+}$cell counts, leading to the need to initiate anti-retroviral therapy [87]. Another double-blind controlled trial of HIV-1 infected patients randomised to either $250 \mathrm{mg} /$ day of chloroquine or placebo, demonstrated a significant increase in HIV viral RNA in patients not taking anti-retroviral therapy and a decrease in ISG expression [88]. While in vitro experiments in Vero cells showed chloroquine could inhibit the replication of Semliki Forest virus and the closely related Chikungunya virus, these effects were not seen in animal studies where chloroquine was associated with higher viral loads $[89,90]$. In addition, when used to treat Chikungunya viral infection in a clinical trial, chloroquine led to clinical deterioration without significant effect on viral load, which was attributed to a delaying effect on adaptive immunity [90,91].

\subsection{Treatment of SARS-CoV-2 Infections}

The anti-viral applications of hydroxychloroquine and chloroquine have gained renewed interest in the wake of the 2020 SARS-CoV-2 pandemic. In vitro studies of SARS-CoV, responsible for the 
2003 epidemic, demonstrated that chloroquine had an inhibitory effect on viral replication in Vero cells [92-94]. However, intraperitoneal and intranasal injections of chloroquine ultimately induced no effect in vivo in BALB/c mice [95]. Nevertheless, with the emergence of the SARS-CoV-2 global pandemic, several in vitro studies have demonstrated hydroxychloroquine and chloroquine inhibit viral replication of this new strain of coronavirus in Vero cells [96-98]. However, the potential benefits of these drugs in the treatment of SARS-CoV-2 infected patients are highly disputed. Preliminary clinical trials in China claimed that chloroquine treatment might inhibit exacerbation of pneumonia, improve radiographic appearances, enhance virus-negative conversion, and reduce the overall length of the illness [99]. However, the results of these trials are yet to be formally peer-reviewed. A subsequent French trial with 20 SARS-CoV-2 patients suggested that hydroxychloroquine treatment (at $600 \mathrm{mg}$ daily) significantly reduced viral load [100]. However, methodological concerns, such as a lack of randomisation and unexplained exclusion of patients in the hydroxychloroquine-treated arm (three of which were transferred to intensive care and another died), have since led to the discounting of the study's findings [101]. In a subsequent larger double-blind clinical trial, 81 SARS-CoV-2 infected patients randomised to either low (450 mg twice daily on the first day and once daily for four days) or high dose (600 mg twice daily for 10 days) chloroquine were compared, with both groups also receiving the antibiotic azithromycin. Increased lethality from cardiac effects associated with a prolongation of the corrected QT interval was observed on electrocardiography in the high dose group [102]. As the trial had to be stopped due to safety concerns, the study became underpowered to detect a treatment benefit of chloroquine [102]. An open-label clinical trial was undertaken in China on 150 SARS-CoV-2 infected patients with mild to moderate symptoms. Patients were either randomised to the normal standard of care or treated with hydroxychloroquine at $1200 \mathrm{mg}$ daily for three days followed by a maintenance dose of $800 \mathrm{mg}$ daily for another 2-3 weeks depending on severity [103]. There was no detectable difference in virus-negative conversion, although there was a greater report of adverse effects in the hydroxychloroquine treated patients [103]. There is currently no evidence to show any significant benefit of hydroxychloroquine or chloroquine in SARS-CoV-2 infection and high doses of the drugs may be associated with adverse effects. One explanation for the discrepancy between in vitro and in vivo findings may be due to the use of Vero cells for all in vitro experiments performed with SARS-CoV and SARS-CoV-2, which do not produce type I interferons [92-94,96-98].

In summary, despite various attempts to utilise hydroxychloroquine and chloroquine to control viral infections, they have not demonstrated clinical efficacy in treating any acute viral infections to date, either as a primary or adjunctive therapy. On the contrary, the immunomodulatory effects of hydroxychloroquine and chloroquine at in vivo biological concentrations may be exploited to enhance viral transduction during gene therapy.

\section{Application of Hydroxychloroquine to Viral Vector-Mediated Retinal Gene Therapy}

\subsection{Immune Responses to AAV-Mediated Retinal Gene Therapy}

$A A V$ vectors have been widely utilised in gene therapy to treat a range of retinal genetic diseases due to their broad tissue tropisms, low pathogenicity, and relative low immunogenicity compared to other major viral vectors, such as lentiviruses and adenoviruses. Despite assumptions of immune privilege in the eye and low immunogenicity of AAV, inflammatory responses have been observed following subretinal injections of AAV. For instance, AAV2- and AAV8-injected cynomolgus macaques demonstrated a dose-dependent increase in capsid-specific neutralising antibodies and a systemic $\mathrm{T}$ cell response to the GFP transgene in two of the 14 animals that received high vector doses $\left(1 \times 10^{11}\right.$ vector genomes $(\mathrm{vg}) /$ eye $)$ [104]. Subretinal injection of cynomolgus macaques with an AAV2tYF vector (with three capsid tyrosine to phenylalanine mutations) expressing the gene CNGB3 led to inflammatory responses in the anterior and posterior segments at both $1.2 \times 10^{11}$ and $1.2 \times 10^{12} \mathrm{vg} /$ eye, with one animal developing severe endophthalmitis; all animals had an increase in neutralising antibodies to the AAV2tYF capsid [105]. Cynomolgous macaques injected 
with the AAV7m8 demonstrated high expression of glial fibrillary acidic protein (GFAP) (a marker for glial activation) at the highest vector dose $\left(1 \times 10^{12} \mathrm{vg} / \mathrm{eye}\right)$ [106]. Severe retinal inflammation was detected with signs of lymphocytic retinal infiltrates, perivascular inflammation, loss of RPE, and chronic choroidal inflammation [106]. The presence of a dose-dependent inflammatory response to AAV2-mediated retinal gene therapy was first observed in humans in a phase $1 / 2$ clinical trial treating RPE65-associated Leber congenital amaurosis where five of the eight high dose patients $\left(1 \times 10^{12} \mathrm{vg} / \mathrm{eye}\right)$ had signs of intraocular inflammation, such as anterior uveitis, mild vitritis, and optic disc swelling [15]. In a phase $1 / 2$ clinical trial of AAV2-mediated gene therapy for choroideremia, one of 14 high dose patients $\left(1 \times 10^{11} \mathrm{vg} / \mathrm{eye}\right)$ developed intraocular inflammation in the form of vitritis, retinitis, and choroiditis, which was associated with reduced visual function [17]. Similarly, in a phase 1/2 trial of AAV8-mediated gene therapy for RPGR-associated X-linked retinitis pigmentosa, seven out of nine high dose patients $\left(0.6-4 \times 10^{11} \mathrm{vg} /\right.$ eye $)$ developed steroid-responsive subretinal inflammation associated with transient changes in retinal sensitivity [14]. Typically, inflammatory responses have been controlled in retinal gene therapy trials using a course of systemic immunosuppression (e.g., oral corticosteroid). However, persistent immune responses against the AAV transgene may diminish the long-term durability of the treatment. Currently, it is uncertain whether intraocular inflammation following AAV-mediated retinal gene therapy is directed at the viral capsid, therapeutic cassette, or the transgene product itself. Characterising the exact nature of the immune responses to AAV and devising methods for overcoming these counterproductive responses have become of great interest as gene therapies go from proof-of-concept to clinical application.

Intramuscular injection of recombinant AAV in wildtype mice elicited TLR9-mediated activation of pDCs and a type I interferon response independent of AAV serotype, suggesting that the TLR9-Myd88 pathway was critical for the activation of a $\mathrm{CD}^{+} \mathrm{T}$ cell response against the AAV capsid and transgene [107]. The immunogenic serotype AAVrh32.33 has also been shown to elicit a TLR9-mediated $\mathrm{CD}^{+} \mathrm{T}$ cell response in vivo, which was significantly diminished upon depletion of $\mathrm{CpG}$ sequences (the ligands for TLR9 receptors) in the viral genome [108]. The activation of adaptive immunity against AAV could lead to the production of transgene-specific antibodies, reduced transgene expression, and diminished durability of gene therapy. For instance, in a gene therapy trial for haemophilia B, an AAV serotype 2 vector containing the human Factor IX transgene delivered via hepatic artery infusion, led to a transient therapeutic level of transgene expression lasting 8 weeks due to destruction of transduced hepatocytes by an AAV capsid-specific CD8 ${ }^{+}$T cell response [109]. While AAVs containing self-complementary genomes can provide higher levels of transgene expression in vitro, they are associated with greater pro-inflammatory innate immune responses in vivo as the double-stranded AAV genome can activate TLR9 more strongly than ssDNA in standard AAV vectors [110]. Furthermore, we found that mouse embryonic fibroblasts lacking cGAS, which is capable of sensing secondary structures of ssDNA such as the AAV ITRs, showed significant increases AAV transgene expression compared with wildtype cells, suggesting that nucleic acid-sensing innate immune responses may be a key limiting factor for AAV transduction [111]. Together, these studies reveal the ability for AAV, similar to other viruses, to activate PRRs and elicit both intracellular and cellular immune responses that can determine the efficacy of gene therapy.

Key anti-viral sensors, including TLR9 and cGAS, and effectors, including IFN- $\gamma$, TNF- $\alpha$, and IL-1 $\beta$ are upregulated in the retina following AAV gene therapy in vivo, in wildtype mice and non-human primates [111-113]. Release of pro-inflammatory cytokines within the retina can lead to increased permeability of the blood-retina barrier and enable infiltration of circulating leukocytes into the normally "immune-privileged" retinal environment [114-116]. This is supported by positive retinal immunohistochemical staining for MHC class I and II (suggestive of active antigen presentation) and CD8 (indicative of infiltrating cytotoxic T cells) following subretinal injection of AAV8 in non-human primates [112]. One possible source of retinal inflammation following AAV gene therapy may be related to the activation of retinal microglia, which are resident macrophage-like cells capable of detecting viral infections and orchestrating local immune responses through the activation of TLR9 [117] and 
cGAS [118], and recruitment of infiltrating leukocytes [119]. This would be consistent with increased immunohistochemical staining for ionized calcium-binding adaptor molecule 1 (IBA1) (a microglia activation marker) in the retina following subretinal injection of AAV in mice [112,113].

\subsection{Improving the Efficacy of Retinal Gene Therapy}

Since hydroxychloroquine and chloroquine are inhibitors of the anti-viral PRRs TLR9 and cGAS, they may provide a means of improving AAV transduction by modulating anti-viral responses during gene therapy. We tested this hypothesis by examining the effect of hydroxychloroquine on AAV2 transduction in vitro at a range of concentrations and found a significant increase in transgene expression at around $19 \mu \mathrm{M}$ of hydroxychloroquine [111]. Similar enhancing effects on AAV transduction were observed in primary non-human primate retinal pigment epithelium (RPE) cells and human retina explants [111]. Co-administration of AAV vector and $19 \mu \mathrm{M}$ hydroxychloroquine via subretinal injection in mice led to improved transgene expression compared with vector alone using both an AAV2 vector with a ubiquitous CAG promoter (4.6-fold improvement) and an AAV8(Y733F) vector with a photoreceptor-specific promoter (GRK1) (5.9-fold improvement) [111]. However, additional in vivo studies with therapeutic vectors and different AAV doses would be beneficial to further investigate the efficacy of hydroxychloroquine in retinal gene therapy.

The suppression of anti-viral pathways by hydroxychloroquine or chloroquine may ultimately prevent expression of downstream pro-inflammatory cytokines and recruitment of infiltrating leukocytes to the retina following AAV gene therapy. In addition, the cytokine IL-6, which has been shown to be inhibited by hydroxychloroquine and chloroquine, can induce B cell maturation and antibody production [42]. This may be of particular concern in patients seronegative for anti-AAV antibodies where AAV gene therapy to the first eye may lead to $B$ cell maturation and the production of anti-AAV antibodies that could diminish the efficacy of repeat treatment to the second eye at a later date. Although AAV2 capsid-specific antibodies and T cell responses have been seen in animal models following readministration via the subretinal route [120], no such reaction was seen in a trial with 11 patients [121]. Nonetheless, transduction of the second eye did not seem to be significantly affected in either cases [120,121]. On the other hand, intravitreal administration of AAV appears to induce a significantly greater level of anti-AAV antibody response [122] and is more prone to antibody-mediated reduction of AAV transduction over repeated treatments [123]. This may be because of increased vector shedding in intravitreal AAV delivery [124], while the blood-retina barrier may limit exposure to circulating antibodies and immune cells during subretinal injections. Therefore, adjunctive therapy with hydroxychloroquine might be beneficial in intravitreally delivered retinal gene therapies by reducing the level of AAV neutralising antibody production to facilitate second eye treatment. Alternatively, the endopeptidase imlifidase (IdeS) has been developed as a means of eliminating anti-AAV antibodies [125]. Cynomologus macaques with pre-existing anti-AAV8 antibodies were intravenously injected with IdeS $24 \mathrm{~h}$ prior to AAV8-hFIX injections. This led to decreased titres of AAV8-specific IgG and neutralising antibodies and a significant increase in hFIX transgene expression. IdeS also enabled readministration of the novel AAV variant AAV-LK03 in African green monkeys, leading to a significant increase in transgene expression [125]. It remains to be seen whether such methods would prove effective in retinal gene therapy given that neutralising antibody responses are minimal following subretinal AAV injections [17]. Nonetheless, anti-AAV antibodies have been detected in some retinal gene therapy clinical trials following subretinal [15] and intravitreal injections [126,127], thus further work is necessary to determine the effect of retinal gene therapy on neutralising antibody responses.

Corticosteroids provide an additional means of controlling AAV-mediated inflammation and have been widely used in retinal gene therapy trials to control inflammatory responses $[11,14,17]$. Corticosteroid activity exists at the apex of an extensive signalling pathway that blocks several downstream inflammatory responses. For instance, by inducing expression of the anti-inflammatory molecule mitogen-activated protein kinase (MAPK) phosphatase 1; preventing transcriptional activity 
of nuclear factor kappa-light-chain-enhancer of activated B cells (NF- $\mathrm{kB}$ ) that regulates downstream transcription of a vast range of cytokines; and blocking c-Jun-mediated transcription of innate immune factors [128]. However, despite this significant anti-inflammatory activity, little is known about the effect of corticosteroids on the efficacy of retinal gene therapy. In vivo studies to investigate the level of retinal transduction with and without corticosteroid treatment would thus be of significant interest. Further work is therefore needed to analyse the mechanism of the AAV-mediated immune responses and how these may be modified using adjunctive treatments during gene therapy.

\section{Safety and Delivery of Hydroxychloroquine in Retinal Gene Therapy}

\subsection{Hydroxychloroquine Retinopathy}

Although the first cases of retinopathy associated with chloroquine therapy were described in the late 1950s [129], retinal toxicity was considered infrequent until the turn of the century as only patients with symptoms of hydroxychloroquine retinopathy were detected [130]. The recognition of an increased risk of retinopathy in chloroquine users, as compared to hydroxychloroquine users, led to the reduction in the use of chloroquine across its treatment indications [131]. However, modern retinal imaging techniques, such as optical coherence tomography (OCT) and fundus autofluorescence, over the past 20 years have enabled the detection of pre-symptomatic disease [132]. Using such techniques, a major case-control study identified the prevalence of hydroxychloroquine retinopathy at $7.5 \%$ of patients taking the drug for more than 5 years, increasing to $20-50 \%$ after 20 years of therapy [133]. The risk factors for retinopathy included daily dose, duration of therapy, renal impairment, and concurrent tamoxifen therapy [133]. A daily dose of $>5 \mathrm{mg} / \mathrm{kg} /$ day over a prolonged period was considered to confer a greater risk of hydroxychloroquine retinopathy [133], and safe dosing guidelines for chronic use of hydroxychloroquine were defined by this threshold [134]. Due to the risk of hydroxychloroquine retinopathy following chronic use, screening programmes were recommended in several countries to reduce the risk of permanent visual loss in this group [135,136]. It is important to note that clinically, hydroxychloroquine and chloroquine are not bioequivalent, and different daily doses are needed to achieve similar therapeutic effects. The safe limits of daily dosing with regards to retinopathy also differ, with $5 \mathrm{mg} / \mathrm{kg} /$ day for hydroxychloroquine and $2.3 \mathrm{mg} / \mathrm{kg} /$ day for chloroquine [136].

\subsection{Routes of Administration}

The adjuvant use of hydroxychloroquine to augment the effects of gene therapy at the time of AAV vector delivery requires some consideration of the route of delivery of hydroxychloroquine, the dose administered and the duration of therapy. The safe limits of orally administered hydroxychloroquine have been defined over the past 60 years. Although there is no identified safe dose which confers no risk, retinopathy is unlikely in the first 5 years of therapy unless concomitant risk factors are present [133]. Very high doses of hydroxychloroquine (1000 mg/day) used in clinical trials in oncology, where hydroxychloroquine is used as an inhibitor of autophagy, have resulted in retinopathy in two out of seven patients at 15 and 25 months, respectively $[137,138]$. Although the mechanism of retinal toxicity of systemically administered hydroxychloroquine is unknown, the dosing characteristics which produce retinopathy have been well described. In the context of retinal gene therapy, it is unlikely that short courses of orally administered hydroxychloroquine in the peri-operative period will have any detectable effects on retinal structure or function, even at a high daily dose of $1000 \mathrm{mg} /$ day.

Although the systemic adjunctive use of hydroxychloroquine in retinal gene therapy has not yet been tested, this approach may be problematic given what is known about the pharmacokinetics of the drug. Hydroxychloroquine has a relatively long plasma half-life of 32 days, and elimination half-life in blood is approximately 50 days. The drug is highly sequestered in tissues, and therefore a steady-state plasma concentration is only achieved after 6 months of daily dosing [139]. Moreover, a study evaluating serum hydroxychloroquine levels in different individuals identified significant variability between subjects [140]. Thus, a consistent and predictable tissue concentration of hydroxychloroquine 
within the retina to enhance AAV retinal gene therapy would be difficult to achieve over a short interval. Furthermore, given that the effects of hydroxychloroquine on the intracellular innate immune response appear highly dose-dependent, this variability in tissue drug concentrations may have a significant influence on retinal photoreceptor or RPE transduction. A greater variability in clinical outcome measures might, therefore, be expected when compared to locally delivered hydroxychloroquine. Rabbit models have demonstrated the sequestration of systemically administered hydroxychloroquine within the pigmented tissues of the eye, such as the RPE, choroid, and ciliary body, where it is bound to melanin [141]. It is unclear how the immunomodulatory effects of hydroxychloroquine may influence the relative efficiency of transduction of AAV-delivered transgenes to the RPE or photoreceptors given this RPE-predominant tissue distribution from systemically administered hydroxychloroquine. Although the effects of systemically administered hydroxychloroquine have not been evaluated in any AAV gene therapy studies, it is likely that hydroxychloroquine would need to be administered in the weeks prior to AAV delivery to allow hydroxychloroquine to reach appropriate tissue concentrations within the eye. Both the efficacy of systemic hydroxychloroquine in the context of retinal gene therapy and tissue concentrations of hydroxychloroquine within the retina and RPE require further evaluation.

The delivery of hydroxychloroquine by subretinal injection allows for precise control over the local drug concentration. In 2013, an in vitro study used chloroquine at $100 \mu \mathrm{M}$ as a tool for alkalising endosomes, a concentration known to raise the $\mathrm{pH}$ of these compartments, and demonstrated a decrease in AAV transduction in a hepatocellular carcinoma cell line (HepG2) [142]. In contrast, we showed that $19 \mu \mathrm{M}$ hydroxychloroquine enhanced AAV-mediated transgene expression in vivo by around 5-fold [111]. The lower concentration of hydroxychloroquine used would primarily be expected to have an immunomodulatory effect and minimal influence on endosomal $\mathrm{pH}$. When comparing the effects of low $(19 \mu \mathrm{M})$ versus high $(113 \mu \mathrm{M})$ dose of hydroxychloroquine co-administered subretinally with $\mathrm{AAV}$ in vivo, we found that $19 \mu \mathrm{M}$ hydroxychloroquine led to significantly increased transgene expression, while $113 \mu \mathrm{M}$ hydroxychloroquine had no effect or in some cases a negative effect on AAV transduction (Figure 3A). Moreover, no retinal structural change was detected by OCT with this single low dose of hydroxychloroquine (Figure 3B) [111]. Given that hydroxychloroquine was only delivered as a one-off treatment together with the AAV vector, the toxic effects associated with prolonged hydroxychloroquine treatment are unlikely. However, long-term assessment of retinal function using an electroretinogram would be required to fully investigate the safety of subretinally delivering hydroxychloroquine. Taken together, these findings are consistent with the hypothesis that a low concentration of locally delivered hydroxychloroquine could improve viral transgene expression by inhibiting PRR-mediated anti-viral responses, while high concentrations of hydroxychloroquine may impair viral entry by altering endosomal $\mathrm{pH}$.

\subsection{Potential Clinical Applications}

Current AAV retinal gene therapy trials and therapeutic protocols, in the case of voretigene neparvovec for $R P E 65$-associated Leber congenital amaurosis, generally include a perioperative period of systemic immunosuppression with prednisolone to reduce the risk of retinal inflammation $[11,14,17]$. Nevertheless, at high vector doses cases of intraocular inflammation have been observed requiring supplementary corticosteroid treatment. This can include oral prednisolone, dexamethasone eye drops, and intravitreal dexamethasone implants (Ozurdex), as demonstrated in the phase 1/2 dose-escalation gene therapy trial for X-linked retinitis pigmentosa [14]. Corticosteroids provide an effective means of controlling ocular inflammation; however, systemic corticosteroid usage may be associated with a range of potential adverse effects, including activation of viral retinitis in previously immunocompetent patients $[143,144]$. Intraocular or periocular corticosteroid use may also be associated with an increased risk of acute retinal necrosis secondary to HSV $[145,146]$. Since the dose of hydroxychloroquine administered in the sub-retinal space in AAV gene therapy potentiates viral action, there is a theoretical risk of viral retinitis. However, acute retinal necrosis has not been reported in long-term systemic hydroxychloroquine users despite clear evidence for drug accumulation 
within the RPE. Hydroxychloroquine in the context of subretinal delivery may, therefore, function as an immunomodulatory rather than immunosuppressive agent. This may suggest that subretinal administration of a single low dose of hydroxychloroquine as an adjuvant to AAV gene therapy is of low risk while offering the potential to reduce the AAV dose required, thus reducing the risk of treatment-induced retinal inflammation and the need for systemic steroids to counter this response. However, while existing evidence supports the safety of low dose hydroxychloroquine in healthy retinae, it is unclear whether the degenerate RPE and photoreceptors in inherited retinal dystrophies may respond differently to the same concentration of hydroxychloroquine.

A

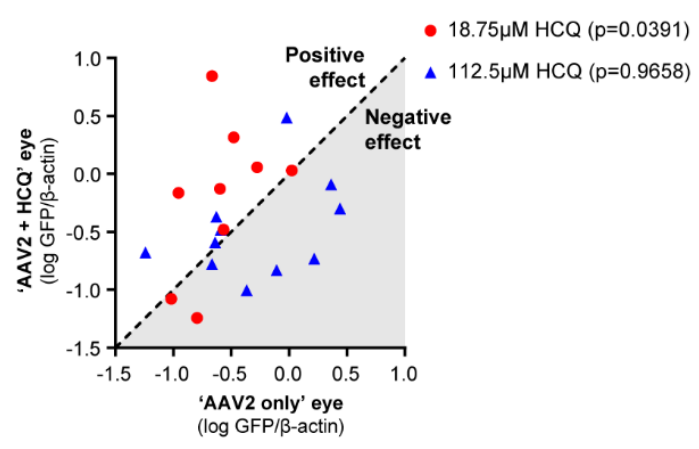

B

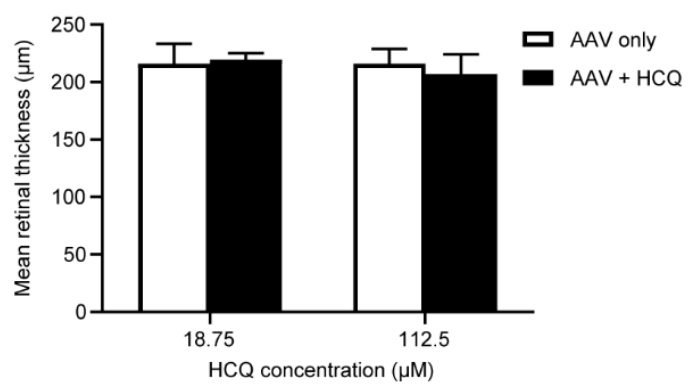

Figure 3. Dose effect of HCQ on improving the efficacy of adeno-associated viral (AAV)-mediated retinal gene therapy in vivo. C57BL/6J mice were subretinally injected with $1 \times 10^{8}$ vector genomes of AAV8(Y733F) GRK1.GFP with and without either $18.75 \mu \mathrm{M}(n=10)$ or $112.5 \mu \mathrm{M}(n=11) \mathrm{HCQ}$. (A) The protein quantification of GFP expression normalised to $\beta$-actin (expressed as $\log _{10}$ ) 6 weeks post-injection of AAV only injected eyes ( $x$-axis) plotted against AAV with HCQ injected eyes ( $y$-axis). Each point represents an individual animal. Points above the line represent a positive effect and below a negative. The $\mathrm{p}$-value for analysis between paired eyes is given in the legend using a Wilcoxon matched-pairs signed rank test. (B) Mean total retinal thickness measured by in vivo spectral domain optical coherence tomography imaging ( \pm SEM).

\section{Conclusions}

An important feature of the mechanism of action of HCQ and CQ is their ability to accumulate in intracellular compartments. However, the activity of these drugs within acidic vesicles may largely rely on their concentration. High doses of HCQ and CQ can alkalise endosomes and lysosomes to impair their function, while low doses appear to have minimal effects on $\mathrm{pH}$ but can prevent activation of intracellular PRRs to modulate downstream innate immune responses. This dual activity may explain the contradictory effects of HCQ and CQ seen in viral infections, with low concentrations providing potential to minimise anti-viral responses. AAV gene therapy is a promising treatment for inherited retinal disease; however, clinical efficacy is limited by the proportion of target cells that successfully express the therapeutic transgene. Adjunctive use of HCQ provides a means of inhibiting restrictive anti-viral intracellular immune responses to improve transgene expression and enhance the therapeutic effect to reach the transduction threshold needed to prevent disease progression. Given the risk of deleterious tissue inflammation with high doses of AAV, HCQ may also enable the use of lower and safer vector doses to achieve a given treatment effect. When applied to viral infections in general, it remains to be seen whether an optimal dosage of HCQ may be found to reduce unwanted tissue inflammation due to anti-viral immune responses in order to reduce overall disease severity or duration.

Author Contributions: Conceptualisation, L.C.C. and K.X.; formal analysis, L.C.C.; investigation, L.C.C., M.E.M. and A.R.B.; writing-original draft preparation, L.C.C. and I.H.Y.; writing-review and editing, L.C.C., I.H.Y., M.E.M., A.R.B., R.E.M. and K.X.; supervision, R.E.M. and K.X.; funding acquisition, I.H.Y., R.E.M. and K.X. All authors have read and agreed to the published version of the manuscript. 
Funding: This research was funded by support from Fight for Sight UK (L.C.C. and K.X.), the Medical Research Council (MRC) (I.H.Y), National Institute for Health Research (NIHR) Oxford Biomedical Research Centre (M.E.M. and R.E.M.), the Wellcome Trust (K.X.), and the Academy of Medical Sciences (K.X.).

Conflicts of Interest: L.C.C., A.R.B., R.E.M. and K.X. hold a patent on behalf of the University of Oxford relating to the use of hydroxychloroquine as an adjunct for gene therapy. The funders had no role in the design of the study; in the collection, analyses, or interpretation of data; in the writing of the manuscript, or in the decision to publish the results.

\section{Abbreviations}

$\begin{array}{ll}\text { AAV } & \text { Adeno-associated virus } \\ \text { HCQ } & \text { Hydroxychloroquine } \\ \text { CQ } & \text { Chloroquine } \\ \text { ssDNA } & \text { Single-stranded DNA } \\ \text { ITR } & \text { Inverted terminal repeat } \\ \text { HIV } & \text { Human immunodeficiency virus } \\ \text { TLR } & \text { Toll-like receptor } \\ \text { PRR } & \text { Pattern recognition receptor } \\ \text { dsRNA } & \text { Double-stranded RNA } \\ \text { ssRNA } & \text { Single-stranded RNA } \\ \text { ODN } & \text { Oligodeoxynucleotide } \\ \text { PBMC } & \text { Peripheral blood mononuclear cell } \\ \text { cGAS } & \text { Cyclic GMP-AMP synthase } \\ \text { IFN } & \text { Interferon } \\ \text { TNF } & \text { Tumour necrosis factor } \\ \text { IL } & \text { Interleukin } \\ \text { ISG } & \text { Interferon-stimulated gene } \\ \text { MHC } & \text { Major histocompatibility complex } \\ \text { HSV } & \text { Herpes simplex virus } \\ \text { SARS-CoV } & \text { Severe acute respiratory syndrome coronavirus } \\ \text { pDC } & \text { Plasmacytoid dendritic cell } \\ \text { vg } & \text { Vector genomes } \\ \text { OCT } & \text { Optical coherence tomography } \\ \end{array}$

\section{References}

1. Schrezenmeier, E.; Dorner, T. Mechanisms of action of hydroxychloroquine and chloroquine: Implications for rheumatology. Nat. Rev. Rheumatol. 2020, 16, 155-166. [CrossRef] [PubMed]

2. Fox, R.I. Mechanism of action of hydroxychloroquine as an antirheumatic drug. Semin. Arthritis Rheum. 1993, 23, 82-91. [CrossRef]

3. Ohkuma, S.; Poole, B. Fluorescence probe measurement of the intralysosomal $\mathrm{pH}$ in living cells and the perturbation of $\mathrm{pH}$ by various agents. Proc. Natl. Acad. Sci. USA 1978, 75, 3327-3331. [CrossRef] [PubMed]

4. Manzel, L.; Strekowski, L.; Ismail, F.M.; Smith, J.C.; Macfarlane, D.E. Antagonism of immunostimulatory CpG-oligodeoxynucleotides by 4-aminoquinolines and other weak bases: Mechanistic studies. J. Pharmacol. Exp. Ther. 1999, 291, 1337-1347. [PubMed]

5. Macfarlane, D.E.; Manzel, L. Antagonism of immunostimulatory CpG-oligodeoxynucleotides by quinacrine, chloroquine, and structurally related compounds. J. Immunol. 1998, 160, 1122-1131.

6. Kuznik, A.; Bencina, M.; Svajger, U.; Jeras, M.; Rozman, B.; Jerala, R. Mechanism of endosomal TLR inhibition by antimalarial drugs and imidazoquinolines. J. Immunol. 2011, 186, 4794-4804. [CrossRef]

7. Duan, D.; Sharma, P.; Yang, J.; Yue, Y.; Dudus, L.; Zhang, Y.; Fisher, K.J.; Engelhardt, J.F. Circular intermediates of recombinant adeno-associated virus have defined structural characteristics responsible for long-term episomal persistence in muscle tissue. J. Virol. 1998, 72, 8568-8577. [CrossRef]

8. Rabinowitz, J.; Chan, Y.K.; Samulski, R.J. Adeno-associated Virus (AAV) versus Immune Response. Viruses 2019, 11, 102. [CrossRef] 
9. Bainbridge, J.W.; Smith, A.J.; Barker, S.S.; Robbie, S.; Henderson, R.; Balaggan, K.; Viswanathan, A.; Holder, G.E.; Stockman, A.; Tyler, N.; et al. Effect of gene therapy on visual function in Leber's congenital amaurosis. N. Engl. J. Med. 2008, 358, 2231-2239. [CrossRef]

10. Pierce, E.A.; Bennett, J. The Status of RPE65 Gene Therapy Trials: Safety and Efficacy. Cold Spring Harb. Perspect Med. 2015, 5, a017285. [CrossRef]

11. Russell, S.; Bennett, J.; Wellman, J.A.; Chung, D.C.; Yu, Z.F.; Tillman, A.; Wittes, J.; Pappas, J.; Elci, O.; McCague, S.; et al. Efficacy and safety of voretigene neparvovec (AAV2-hRPE65v2) in patients with RPE65-mediated inherited retinal dystrophy: A randomised, controlled, open-label, phase 3 trial. Lancet 2017, 390, 849-860. [CrossRef]

12. MacLaren, R.E.; Groppe, M.; Barnard, A.R.; Cottriall, C.L.; Tolmachova, T.; Seymour, L.; Clark, K.R.; During, M.J.; Cremers, F.P.; Black, G.C.; et al. Retinal gene therapy in patients with choroideremia: Initial findings from a phase $1 / 2$ clinical trial. Lancet 2014, 383, 1129-1137. [CrossRef]

13. Edwards, T.L.; Jolly, J.K.; Groppe, M.; Barnard, A.R.; Cottriall, C.L.; Tolmachova, T.; Black, G.C.; Webster, A.R.; Lotery, A.J.; Holder, G.E.; et al. Visual Acuity after Retinal Gene Therapy for Choroideremia. N. Engl. J. Med. 2016, 374, 1996-1998. [CrossRef] [PubMed]

14. Cehajic-Kapetanovic, J.; Xue, K.; Martinez-Fernandez de la Camara, C.; Nanda, A.; Davies, A.; Wood, L.J.; Salvetti, A.P.; Fischer, M.D.; Aylward, J.W.; Barnard, A.R.; et al. Initial results from a first-in-human gene therapy trial on X-linked retinitis pigmentosa caused by mutations in RPGR. Nat. Med. 2020, 26, 354-359. [CrossRef]

15. Bainbridge, J.W.; Mehat, M.S.; Sundaram, V.; Robbie, S.J.; Barker, S.E.; Ripamonti, C.; Georgiadis, A.; Mowat, F.M.; Beattie, S.G.; Gardner, P.J.; et al. Long-term effect of gene therapy on Leber's congenital amaurosis. N. Engl. J. Med. 2015, 372, 1887-1897. [CrossRef]

16. Guy, J.; Feuer, W.J.; Davis, J.L.; Porciatti, V.; Gonzalez, P.J.; Koilkonda, R.D.; Yuan, H.; Hauswirth, W.W.; Lam, B.L. Gene Therapy for Leber Hereditary Optic Neuropathy: Low- and Medium-Dose Visual Results. Ophthalmology 2017, 124, 1621-1634. [CrossRef]

17. Xue, K.; Jolly, J.K.; Barnard, A.R.; Rudenko, A.; Salvetti, A.P.; Patrício, M.I.; Edwards, T.L.; Groppe, M.; Orlans, H.O.; Tolmachova, T.; et al. Beneficial effects on vision in patients undergoing retinal gene therapy for choroideremia. Nat. Med. 2018, 24, 1507-1512. [CrossRef]

18. Ben-Zvi, I.; Kivity, S.; Langevitz, P.; Shoenfeld, Y. Hydroxychloroquine: From malaria to autoimmunity. Clin. Rev. Allergy Immunol. 2012, 42, 145-153. [CrossRef]

19. Pandey, S.; Kawai, T.; Akira, S. Microbial sensing by Toll-like receptors and intracellular nucleic acid sensors. Cold Spring Harb. Perspect. Biol. 2014, 7, a016246. [CrossRef]

20. Ewald, S.E.; Lee, B.L.; Lau, L.; Wickliffe, K.E.; Shi, G.P.; Chapman, H.A.; Barton, G.M. The ectodomain of Toll-like receptor 9 is cleaved to generate a functional receptor. Nature 2008, 456, 658-662. [CrossRef]

21. Alexopoulou, L.; Holt, A.C.; Medzhitov, R.; Flavell, R.A. Recognition of double-stranded RNA and activation of NF-kappaB by Toll-like receptor 3. Nature 2001, 413, 732-738. [CrossRef]

22. Heil, F.; Hemmi, H.; Hochrein, H.; Ampenberger, F.; Kirschning, C.; Akira, S.; Lipford, G.; Wagner, H.; Bauer, S. Species-specific recognition of single-stranded RNA via toll-like receptor 7 and 8. Science 2004, 303, 1526-1529. [CrossRef] [PubMed]

23. Hemmi, H.; Takeuchi, O.; Kawai, T.; Kaisho, T.; Sato, S.; Sanjo, H.; Matsumoto, M.; Hoshino, K.; Wagner, H.; Takeda, K.; et al. A Toll-like receptor recognizes bacterial DNA. Nature 2000, 408, 740-745. [CrossRef] [PubMed]

24. Bird, A.P. CpG-rich islands and the function of DNA methylation. Nature 1986, 321, 209-213. [CrossRef] [PubMed]

25. Hacker, H.; Mischak, H.; Miethke, T.; Liptay, S.; Schmid, R.; Sparwasser, T.; Heeg, K.; Lipford, G.B.; Wagner, H. CpG-DNA-specific activation of antigen-presenting cells requires stress kinase activity and is preceded by non-specific endocytosis and endosomal maturation. EMBO J. 1998, 17, 6230-6240. [CrossRef]

26. Rutz, M.; Metzger, J.; Gellert, T.; Luppa, P.; Lipford, G.B.; Wagner, H.; Bauer, S. Toll-like receptor 9 binds single-stranded CpG-DNA in a sequence- and pH-dependent manner. Eur. J. Immunol. 2004, 34, 2541-2550. [CrossRef] [PubMed]

27. Lamphier, M.; Zheng, W.; Latz, E.; Spyvee, M.; Hansen, H.; Rose, J.; Genest, M.; Yang, H.; Shaffer, C.; Zhao, Y.; et al. Novel small molecule inhibitors of TLR7 and TLR9: Mechanism of action and efficacy in vivo. Mol. Pharmacol. 2014, 85, 429-440. [CrossRef] 
28. de Bouteiller, O.; Merck, E.; Hasan, U.A.; Hubac, S.; Benguigui, B.; Trinchieri, G.; Bates, E.E.; Caux, C. Recognition of double-stranded RNA by human toll-like receptor 3 and downstream receptor signaling requires multimerization and an acidic pH. J. Biol. Chem. 2005, 280, 38133-38145. [CrossRef]

29. Vollmer, J.; Tluk, S.; Schmitz, C.; Hamm, S.; Jurk, M.; Forsbach, A.; Akira, S.; Kelly, K.M.; Reeves, W.H.; Bauer, S.; et al. Immune stimulation mediated by autoantigen binding sites within small nuclear RNAs involves Toll-like receptors 7 and 8. J. Exp. Med. 2005, 202, 1575-1585. [CrossRef]

30. Sun, L.; Wu, J.; Du, F.; Chen, X.; Chen, Z.J. Cyclic GMP-AMP synthase is a cytosolic DNA sensor that activates the type I interferon pathway. Science 2013, 339, 786-791. [CrossRef]

31. Wu, J.; Sun, L.; Chen, X.; Du, F.; Shi, H.; Chen, C.; Chen, Z.J. Cyclic GMP-AMP is an endogenous second messenger in innate immune signaling by cytosolic DNA. Science 2013, 339, 826-830. [CrossRef] [PubMed]

32. An, J.; Woodward, J.J.; Sasaki, T.; Minie, M.; Elkon, K.B. Cutting edge: Antimalarial drugs inhibit IFN-beta production through blockade of cyclic GMP-AMP synthase-DNA interaction. J. Immunol. 2015, 194, 4089-4093. [CrossRef] [PubMed]

33. An, J.; Minie, M.; Sasaki, T.; Woodward, J.J.; Elkon, K.B. Antimalarial Drugs as Immune Modulators: New Mechanisms for Old Drugs. Annu. Rev. Med. 2017, 68, 317-330. [CrossRef] [PubMed]

34. Bose, D.; Su, Y.; Marcus, A.; Raulet, D.H.; Hammond, M.C. An RNA-Based Fluorescent Biosensor for High-Throughput Analysis of the cGAS-cGAMP-STING Pathway. Cell Chem. Biol. 2016, 23, 1539-1549. [CrossRef] [PubMed]

35. Means, T.K.; Latz, E.; Hayashi, F.; Murali, M.R.; Golenbock, D.T.; Luster, A.D. Human lupus autoantibody-DNA complexes activate DCs through cooperation of CD32 and TLR9. J. Clin. Investig. 2005, 115, 407-417. [CrossRef]

36. Barrat, F.J.; Meeker, T.; Gregorio, J.; Chan, J.H.; Uematsu, S.; Akira, S.; Chang, B.; Duramad, O.; Coffman, R.L. Nucleic acids of mammalian origin can act as endogenous ligands for Toll-like receptors and may promote systemic lupus erythematosus. J. Exp. Med. 2005, 202, 1131-1139. [CrossRef]

37. Kato, Y.; Park, J.; Takamatsu, H.; Konaka, H.; Aoki, W.; Aburaya, S.; Ueda, M.; Nishide, M.; Koyama, S.; Hayama, Y.; et al. Apoptosis-derived membrane vesicles drive the cGAS-STING pathway and enhance type I IFN production in systemic lupus erythematosus. Ann. Rheum. Dis. 2018, 77, 1507-1515. [CrossRef]

38. An, J.; Durcan, L.; Karr, R.M.; Briggs, T.A.; Rice, G.I.; Teal, T.H.; Woodward, J.J.; Elkon, K.B. Expression of Cyclic GMP-AMP Synthase in Patients with Systemic Lupus Erythematosus. Arthritis Rheumatol. 2017, 69, 800-807. [CrossRef]

39. van den Borne, B.E.; Dijkmans, B.A.; de Rooij, H.H.; le Cessie, S.; Verweij, C.L. Chloroquine and hydroxychloroquine equally affect tumor necrosis factor-alpha, interleukin 6, and interferon-gamma production by peripheral blood mononuclear cells. J. Rheumatol. 1997, 24, 55-60.

40. Jang, C.H.; Choi, J.H.; Byun, M.S.; Jue, D.M. Chloroquine inhibits production of TNF-alpha, IL-1beta and IL-6 from lipopolysaccharide-stimulated human monocytes/macrophages by different modes. Rheumatology (Oxford) 2006, 45, 703-710. [CrossRef]

41. Ivashkiv, L.B. IFNgamma: Signalling, epigenetics and roles in immunity, metabolism, disease and cancer immunotherapy. Nat. Rev. Immunol. 2018, 18, 545-558. [CrossRef] [PubMed]

42. Hunter, C.A.; Jones, S.A. IL-6 as a keystone cytokine in health and disease. Nat. Immunol. 2015, 16, 448-457. [CrossRef] [PubMed]

43. Parameswaran, N.; Patial, S. Tumor necrosis factor-alpha signaling in macrophages. Crit. Rev. Eukaryot Gene Expr. 2010, 20, 87-103. [CrossRef] [PubMed]

44. Schmidt, R.L.; Jutz, S.; Goldhahn, K.; Witzeneder, N.; Gerner, M.C.; Trapin, D.; Greiner, G.; Hoermann, G.; Steiner, G.; Pickl, W.F.; et al. Chloroquine inhibits human CD4(+) T-cell activation by AP-1 signaling modulation. Sci. Rep. 2017, 7, 42191. [CrossRef]

45. Schneider, W.M.; Chevillotte, M.D.; Rice, C.M. Interferon-stimulated genes: A complex web of host defenses. Annu Rev. Immunol. 2014, 32, 513-545. [CrossRef]

46. Perng, Y.C.; Lenschow, D.J. ISG15 in antiviral immunity and beyond. Nat. Rev. Microbiol. 2018, 16, 423-439. [CrossRef]

47. Nguyen, K.B.; Salazar-Mather, T.P.; Dalod, M.Y.; Van Deusen, J.B.; Wei, X.Q.; Liew, F.Y.; Caligiuri, M.A.; Durbin, J.E.; Biron, C.A. Coordinated and distinct roles for IFN-alpha beta, IL-12, and IL-15 regulation of NK cell responses to viral infection. J. Immunol. 2002, 169, 4279-4287. [CrossRef] 
48. Zhang, X.; Sun, S.; Hwang, I.; Tough, D.F.; Sprent, J. Potent and selective stimulation of memory-phenotype CD8+ T cells in vivo by IL-15. Immunity 1998, 8, 591-599. [CrossRef]

49. Munz, C. Autophagy Beyond Intracellular MHC Class II Antigen Presentation. Trends Immunol. 2016, 37, 755-763. [CrossRef]

50. Ziegler, H.K.; Unanue, E.R. Decrease in macrophage antigen catabolism caused by ammonia and chloroquine is associated with inhibition of antigen presentation to T cells. Proc. Natl. Acad. Sci. USA 1982, 79, 175-178. [CrossRef]

51. Chain, B.M.; Kay, P.M.; Feldmann, M. The cellular pathway of antigen presentation: Biochemical and functional analysis of antigen processing in dendritic cells and macrophages. Immunology 1986, 58, 271-276.

52. Robson, N.C.; Donachie, A.M.; Mowat, A.M. Simultaneous presentation and cross-presentation of immune-stimulating complex-associated cognate antigen by antigen-specific B cells. Eur. J. Immunol. 2008, 38, 1238-1246. [CrossRef]

53. Mauthe, M.; Orhon, I.; Rocchi, C.; Zhou, X.; Luhr, M.; Hijlkema, K.J.; Coppes, R.P.; Engedal, N.; Mari, M.; Reggiori, F. Chloroquine inhibits autophagic flux by decreasing autophagosome-lysosome fusion. Autophagy 2018, 14, 1435-1455. [CrossRef] [PubMed]

54. Nimmerjahn, F.; Milosevic, S.; Behrends, U.; Jaffee, E.M.; Pardoll, D.M.; Bornkamm, G.W.; Mautner, J. Major histocompatibility complex class II-restricted presentation of a cytosolic antigen by autophagy. Eur. J. Immunol. 2003, 33, 1250-1259. [CrossRef] [PubMed]

55. Dengjel, J.; Schoor, O.; Fischer, R.; Reich, M.; Kraus, M.; Muller, M.; Kreymborg, K.; Altenberend, F.; Brandenburg, J.; Kalbacher, H.; et al. Autophagy promotes MHC class II presentation of peptides from intracellular source proteins. Proc. Natl. Acad. Sci. USA 2005, 102, 7922-7927. [CrossRef] [PubMed]

56. Paludan, C.; Schmid, D.; Landthaler, M.; Vockerodt, M.; Kube, D.; Tuschl, T.; Munz, C. Endogenous MHC class II processing of a viral nuclear antigen after autophagy. Science 2005, 307, 593-596. [CrossRef]

57. Rosenfeld, M.R.; Ye, X.; Supko, J.G.; Desideri, S.; Grossman, S.A.; Brem, S.; Mikkelson, T.; Wang, D.; Chang, Y.C.; Hu, J.; et al. A phase I/II trial of hydroxychloroquine in conjunction with radiation therapy and concurrent and adjuvant temozolomide in patients with newly diagnosed glioblastoma multiforme. Autophagy 2014, 10, 1359-1368. [CrossRef]

58. Rangwala, R.; Leone, R.; Chang, Y.C.; Fecher, L.A.; Schuchter, L.M.; Kramer, A.; Tan, K.S.; Heitjan, D.F.; Rodgers, G.; Gallagher, M.; et al. Phase I trial of hydroxychloroquine with dose-intense temozolomide in patients with advanced solid tumors and melanoma. Autophagy 2014, 10, 1369-1379. [CrossRef]

59. Karasic, T.B.; O’Hara, M.H.; Loaiza-Bonilla, A.; Reiss, K.A.; Teitelbaum, U.R.; Borazanci, E.; De Jesus-Acosta, A.; Redlinger, C.; Burrell, J.A.; Laheru, D.A.; et al. Effect of Gemcitabine and nab-Paclitaxel With or Without Hydroxychloroquine on Patients With Advanced Pancreatic Cancer: A Phase 2 Randomized Clinical Trial. JAMA Oncol. 2019, 5, 993-998. [CrossRef]

60. Haas, N.B.; Appleman, L.J.; Stein, M.; Redlinger, M.; Wilks, M.; Xu, X.; Onorati, A.; Kalavacharla, A.; Kim, T.; Zhen, C.J.; et al. Autophagy Inhibition to Augment mTOR Inhibition: A Phase I/II Trial of Everolimus and Hydroxychloroquine in Patients with Previously Treated Renal Cell Carcinoma. Clin. Cancer Res. 2019, 25, 2080-2087. [CrossRef]

61. Vazquez-Calvo, A.; Saiz, J.C.; McCullough, K.C.; Sobrino, F.; Martin-Acebes, M.A. Acid-dependent viral entry. Virus Res. 2012, 167, 125-137. [CrossRef] [PubMed]

62. Helenius, A.; Marsh, M.; White, J. Inhibition of Semliki forest virus penetration by lysosomotropic weak bases. J. Gen. Virol. 1982, 58 Pt 1, 47-61. [CrossRef]

63. Khan, M.; Santhosh, S.R.; Tiwari, M.; Lakshmana Rao, P.V.; Parida, M. Assessment of in vitro prophylactic and therapeutic efficacy of chloroquine against Chikungunya virus in vero cells. J. Med. Virol. 2010, 82, 817-824. [CrossRef] [PubMed]

64. Bishop, N.E. Examination of potential inhibitors of hepatitis A virus uncoating. Intervirology 1998, 41, $261-271$. [CrossRef]

65. Tsai, W.P.; Nara, P.L.; Kung, H.F.; Oroszlan, S. Inhibition of human immunodeficiency virus infectivity by chloroquine. AIDS Res. Hum. Retrovir. 1990, 6, 481-489. [CrossRef]

66. Sperber, K.; Kalb, T.H.; Stecher, V.J.; Banerjee, R.; Mayer, L. Inhibition of human immunodeficiency virus type 1 replication by hydroxychloroquine in T cells and monocytes. AIDS Res. Hum. Retrovir. 1993, 9, 91-98. [CrossRef] [PubMed] 
67. Chiang, G.; Sassaroli, M.; Louie, M.; Chen, H.; Stecher, V.J.; Sperber, K. Inhibition of HIV-1 replication by hydroxychloroquine: Mechanism of action and comparison with zidovudine. Clin. Ther. 1996, 18, 1080-1092. [CrossRef]

68. Harley, C.A.; Dasgupta, A.; Wilson, D.W. Characterization of herpes simplex virus-containing organelles by subcellular fractionation: Role for organelle acidification in assembly of infectious particles. J. Virol. 2001, 75, 1236-1251. [CrossRef]

69. Brenchley, J.M.; Price, D.A.; Schacker, T.W.; Asher, T.E.; Silvestri, G.; Rao, S.; Kazzaz, Z.; Bornstein, E.; Lambotte, O.; Altmann, D.; et al. Microbial translocation is a cause of systemic immune activation in chronic HIV infection. Nat. Med. 2006, 12, 1365-1371. [CrossRef]

70. Peiris, J.S.; Chu, C.M.; Cheng, V.C.; Chan, K.S.; Hung, I.F.; Poon, L.L.; Law, K.I.; Tang, B.S.; Hon, T.Y.; Chan, C.S.; et al. Clinical progression and viral load in a community outbreak of coronavirus-associated SARS pneumonia: A prospective study. Lancet 2003, 361, 1767-1772. [CrossRef]

71. Tay, M.Z.; Poh, C.M.; Renia, L.; MacAry, P.A.; Ng, L.F.P. The trinity of COVID-19: Immunity, inflammation and intervention. Nat. Rev. Immunol. 2020. [CrossRef] [PubMed]

72. Murray, S.M.; Down, C.M.; Boulware, D.R.; Stauffer, W.M.; Cavert, W.P.; Schacker, T.W.; Brenchley, J.M.; Douek, D.C. Reduction of immune activation with chloroquine therapy during chronic HIV infection. J. Virol. 2010, 84, 12082-12086. [CrossRef] [PubMed]

73. Beignon, A.S.; McKenna, K.; Skoberne, M.; Manches, O.; DaSilva, I.; Kavanagh, D.G.; Larsson, M.; Gorelick, R.J.; Lifson, J.D.; Bhardwaj, N. Endocytosis of HIV-1 activates plasmacytoid dendritic cells via Toll-like receptor-viral RNA interactions. J. Clin. Investig. 2005, 115, 3265-3275. [CrossRef]

74. Martinson, J.A.; Montoya, C.J.; Usuga, X.; Ronquillo, R.; Landay, A.L.; Desai, S.N. Chloroquine modulates HIV-1-induced plasmacytoid dendritic cell alpha interferon: Implication for T-cell activation. Antimicrob. Agents Chemother. 2010, 54, 871-881. [CrossRef]

75. Han, X.; Li, X.; Yue, S.C.; Anandaiah, A.; Hashem, F.; Reinach, P.S.; Koziel, H.; Tachado, S.D. Epigenetic regulation of tumor necrosis factor alpha (TNFalpha) release in human macrophages by HIV-1 single-stranded RNA (ssRNA) is dependent on TLR8 signaling. J. Biol. Chem. 2012, 287, 13778-13786. [CrossRef]

76. Lee, J.; Tian, Y.; Chan, S.T.; Kim, J.Y.; Cho, C.; Ou, J.H. TNF-alpha Induced by Hepatitis C Virus via TLR7 and TLR8 in Hepatocytes Supports Interferon Signaling via an Autocrine Mechanism. PLoS Pathog. 2015, 11, e1004937. [CrossRef] [PubMed]

77. Zhang, Y.; El-Far, M.; Dupuy, F.P.; Abdel-Hakeem, M.S.; He, Z.; Procopio, F.A.; Shi, Y.; Haddad, E.K.; Ancuta, P.; Sekaly, R.P.; et al. HCV RNA Activates APCs via TLR7/TLR8 While Virus Selectively Stimulates Macrophages Without Inducing Antiviral Responses. Sci. Rep. 2016, 6, 29447. [CrossRef] [PubMed]

78. Diebold, S.S.; Kaisho, T.; Hemmi, H.; Akira, S.; Reis e Sousa, C. Innate antiviral responses by means of TLR7-mediated recognition of single-stranded RNA. Science 2004, 303, 1529-1531. [CrossRef]

79. Lund, J.M.; Alexopoulou, L.; Sato, A.; Karow, M.; Adams, N.C.; Gale, N.W.; Iwasaki, A.; Flavell, R.A. Recognition of single-stranded RNA viruses by Toll-like receptor 7. Proc. Natl. Acad. Sci. USA 2004, 101, 5598-5603. [CrossRef]

80. Lund, J.; Sato, A.; Akira, S.; Medzhitov, R.; Iwasaki, A. Toll-like receptor 9-mediated recognition of Herpes simplex virus-2 by plasmacytoid dendritic cells. J. Exp. Med. 2003, 198, 513-520. [CrossRef] [PubMed]

81. Quan, T.E.; Roman, R.M.; Rudenga, B.J.; Holers, V.M.; Craft, J.E. Epstein-Barr virus promotes interferon-alpha production by plasmacytoid dendritic cells. Arthritis Rheum. 2010, 62, 1693-1701. [CrossRef] [PubMed]

82. Fiola, S.; Gosselin, D.; Takada, K.; Gosselin, J. TLR9 contributes to the recognition of EBV by primary monocytes and plasmacytoid dendritic cells. J. Immunol. 2010, 185, 3620-3631. [CrossRef] [PubMed]

83. Desmyter, J.; Melnick, J.L.; Rawls, W.E. Defectiveness of interferon production and of rubella virus interference in a line of African green monkey kidney cells (Vero). J. Virol. 1968, 2, 955-961. [CrossRef]

84. Osada, N.; Kohara, A.; Yamaji, T.; Hirayama, N.; Kasai, F.; Sekizuka, T.; Kuroda, M.; Hanada, K. The genome landscape of the african green monkey kidney-derived vero cell line. DNA Res. 2014, 21, 673-683. [CrossRef] [PubMed]

85. Brandriss, M.W.; Schlesinger, J.J. Antibody-mediated infection of P388D1 cells with 17D yellow fever virus: Effects of chloroquine and cytochalasin B. J. Gen. Virol. 1984, 65, 791-794. [CrossRef] [PubMed]

86. Pontesilli, O.; Carotenuto, P.; Levin, M.J.; Suez, D.; Hayward, A.R. Processing and presentation of cell-associated varicella-zoster virus antigens by human monocytes. Clin. Exp. Immunol. 1987, 70, 127-135. [PubMed] 
87. Paton, N.I.; Goodall, R.L.; Dunn, D.T.; Franzen, S.; Collaco-Moraes, Y.; Gazzard, B.G.; Williams, I.G.; Fisher, M.J.; Winston, A.; Fox, J.; et al. Effects of hydroxychloroquine on immune activation and disease progression among HIV-infected patients not receiving antiretroviral therapy: A randomized controlled trial. JAMA 2012, 308, 353-361. [CrossRef]

88. Jacobson, J.M.; Bosinger, S.E.; Kang, M.; Belaunzaran-Zamudio, P.; Matining, R.M.; Wilson, C.C.; Flexner, C.; Clagett, B.; Plants, J.; Read, S.; et al. The Effect of Chloroquine on Immune Activation and Interferon Signatures Associated with HIV-1. AIDS Res. Hum. Retrovir. 2016, 32, 636-647. [CrossRef]

89. Maheshwari, R.K.; Srikantan, V.; Bhartiya, D. Chloroquine enhances replication of Semliki Forest virus and encephalomyocarditis virus in mice. J. Virol. 1991, 65, 992-995. [CrossRef]

90. Roques, P.; Thiberville, S.D.; Dupuis-Maguiraga, L.; Lum, F.M.; Labadie, K.; Martinon, F.; Gras, G.; Lebon, P.; $\mathrm{Ng}$, L.F.P.; de Lamballerie, X.; et al. Paradoxical Effect of Chloroquine Treatment in Enhancing Chikungunya Virus Infection. Viruses 2018, 10, 268. [CrossRef]

91. De Lamballerie, X.; Boisson, V.; Reynier, J.C.; Enault, S.; Charrel, R.N.; Flahault, A.; Roques, P.; Le Grand, R. On chikungunya acute infection and chloroquine treatment. Vector Borne Zoonotic Dis. 2008, 8, 837-839. [CrossRef] [PubMed]

92. Keyaerts, E.; Vijgen, L.; Maes, P.; Neyts, J.; Van Ranst, M. In vitro inhibition of severe acute respiratory syndrome coronavirus by chloroquine. Biochem. Biophys. Res. Commun. 2004, 323, 264-268. [CrossRef] [PubMed]

93. Vincent, M.J.; Bergeron, E.; Benjannet, S.; Erickson, B.R.; Rollin, P.E.; Ksiazek, T.G.; Seidah, N.G.; Nichol, S.T. Chloroquine is a potent inhibitor of SARS coronavirus infection and spread. Virol. J. 2005, 2, 69. [CrossRef] [PubMed]

94. Biot, C.; Daher, W.; Chavain, N.; Fandeur, T.; Khalife, J.; Dive, D.; De Clercq, E. Design and synthesis of hydroxyferroquine derivatives with antimalarial and antiviral activities. J. Med. Chem. 2006, 49, 2845-2849. [CrossRef] [PubMed]

95. Barnard, D.L.; Day, C.W.; Bailey, K.; Heiner, M.; Montgomery, R.; Lauridsen, L.; Chan, P.K.; Sidwell, R.W. Evaluation of immunomodulators, interferons and known in vitro SARS-coV inhibitors for inhibition of SARS-coV replication in BALB/c mice. Antivir. Chem. Chemother. 2006, 17, 275-284. [CrossRef]

96. Wang, M.; Cao, R.; Zhang, L.; Yang, X.; Liu, J.; Xu, M.; Shi, Z.; Hu, Z.; Zhong, W.; Xiao, G. Remdesivir and chloroquine effectively inhibit the recently emerged novel coronavirus (2019-nCoV) in vitro. Cell Res. 2020, 30, 269-271. [CrossRef]

97. Yao, X.; Ye, F.; Zhang, M.; Cui, C.; Huang, B.; Niu, P.; Liu, X.; Zhao, L.; Dong, E.; Song, C.; et al. In Vitro Antiviral Activity and Projection of Optimized Dosing Design of Hydroxychloroquine for the Treatment of Severe Acute Respiratory Syndrome Coronavirus 2 (SARS-CoV-2). Clin. Infect. Dis. 2020, 10. [CrossRef]

98. Liu, J.; Cao, R.; Xu, M.; Wang, X.; Zhang, H.; Hu, H.; Li, Y.; Hu, Z.; Zhong, W.; Wang, M. Hydroxychloroquine, a less toxic derivative of chloroquine, is effective in inhibiting SARS-CoV-2 infection in vitro. Cell Discov. 2020, 6, 16. [CrossRef]

99. Gao, J.; Tian, Z.; Yang, X. Breakthrough: Chloroquine phosphate has shown apparent efficacy in treatment of COVID-19 associated pneumonia in clinical studies. Biosci. Trends 2020, 14, 72-73. [CrossRef]

100. Gautret, P.; Lagier, J.C.; Parola, P.; Hoang, V.T.; Meddeb, L.; Mailhe, M.; Doudier, B.; Courjon, J.; Giordanengo, V.; Vieira, V.E.; et al. Hydroxychloroquine and azithromycin as a treatment of COVID-19: Results of an open-label non-randomized clinical trial. Int. J. Antimicrob. Agents 2020. [CrossRef]

101. Voss, A. Statement on IJAA Paper. Available online: https://www.isac.world/news-and-publications/officialisac-statement (accessed on 30 April 2020).

102. Borba, M.G.S.; Val, F.F.A.; Sampaio, V.S.; Alexandre, M.A.A.; Melo, G.C.; Brito, M.; Mourao, M.P.G.; Brito-Sousa, J.D.; Baia-da-Silva, D.; Guerra, M.V.F.; et al. Effect of High vs Low Doses of Chloroquine Diphosphate as Adjunctive Therapy for Patients Hospitalized With Severe Acute Respiratory Syndrome Coronavirus 2 (SARS-CoV-2) Infection: A Randomized Clinical Trial. JAMA Netw. Open 2020, 3, e208857. [CrossRef] [PubMed]

103. Tang, W.; Cao, Z.; Han, M.; Wang, Z.; Chen, J.; Sun, W.; Wu, Y.; Xiao, W.; Liu, S.; Chen, E.; et al. Hydroxychloroquine in patients with mainly mild to moderate coronavirus disease 2019: Open label, randomised controlled trial. BMJ 2020, 369, m1849. [CrossRef] [PubMed] 
104. Vandenberghe, L.H.; Bell, P.; Maguire, A.M.; Cearley, C.N.; Xiao, R.; Calcedo, R.; Wang, L.; Castle, M.J.; Maguire, A.C.; Grant, R.; et al. Dosage thresholds for AAV2 and AAV8 photoreceptor gene therapy in monkey. Sci. Transl. Med. 2011, 3, 88ra54. [CrossRef] [PubMed]

105. Ye, G.J.; Budzynski, E.; Sonnentag, P.; Nork, T.M.; Miller, P.E.; Sharma, A.K.; Ver Hoeve, J.N.; Smith, L.M.; Arndt, T.; Calcedo, R.; et al. Safety and Biodistribution Evaluation in Cynomolgus Macaques of rAAV2tYF-PR1.7-hCNGB3, a Recombinant AAV Vector for Treatment of Achromatopsia. Hum. Gene Ther. Clin. Dev. 2016, 27, 37-48. [CrossRef]

106. Ramachandran, P.S.; Lee, V.; Wei, Z.; Song, J.Y.; Casal, G.; Cronin, T.; Willett, K.; Huckfeldt, R.; Morgan, J.I.; Aleman, T.S.; et al. Evaluation of Dose and Safety of AAV7m8 and AAV8BP2 in the Non-Human Primate Retina. Hum. Gene Ther. 2017, 28, 154-167. [CrossRef]

107. Zhu, J.; Huang, X.; Yang, Y. The TLR9-MyD88 pathway is critical for adaptive immune responses to adeno-associated virus gene therapy vectors in mice. J. Clin. Investig. 2009, 119, 2388-2398. [CrossRef] [PubMed]

108. Faust, S.M.; Bell, P.; Cutler, B.J.; Ashley, S.N.; Zhu, Y.; Rabinowitz, J.E.; Wilson, J.M. CpG-depleted adeno-associated virus vectors evade immune detection. J. Clin. Investig. 2013, 123, 2994-3001. [CrossRef]

109. Manno, C.S.; Pierce, G.F.; Arruda, V.R.; Glader, B.; Ragni, M.; Rasko, J.J.; Ozelo, M.C.; Hoots, K.; Blatt, P.; Konkle, B.; et al. Successful transduction of liver in hemophilia by AAV-Factor IX and limitations imposed by the host immune response. Nat. Med. 2006, 12, 342-347. [CrossRef]

110. Martino, A.T.; Suzuki, M.; Markusic, D.M.; Zolotukhin, I.; Ryals, R.C.; Moghimi, B.; Ertl, H.C.; Muruve, D.A.; Lee, B.; Herzog, R.W. The genome of self-complementary adeno-associated viral vectors increases Toll-like receptor 9-dependent innate immune responses in the liver. Blood 2011, 117, 6459-6468. [CrossRef]

111. Chandler, L.C.; Barnard, A.R.; Caddy, S.L.; Patricio, M.I.; McClements, M.E.; Fu, H.; Rada, C.; MacLaren, R.E.; Xue, K. Enhancement of Adeno-Associated Virus-Mediated Gene Therapy Using Hydroxychloroquine in Murine and Human Tissues. Mol. Ther. Methods Clin. Dev. 2019, 14, 77-89. [CrossRef]

112. Reichel, F.F.; Dauletbekov, D.L.; Klein, R.; Peters, T.; Ochakovski, G.A.; Seitz, I.P.; Wilhelm, B.; Ueffing, M.; Biel, M.; Wissinger, B.; et al. AAV8 Can Induce Innate and Adaptive Immune Response in the Primate Eye. Mol. Ther. 2017, 25, 2648-2660. [CrossRef] [PubMed]

113. Xiong, W.; Wu, D.M.; Xue, Y.; Wang, S.K.; Chung, M.J.; Ji, X.; Rana, P.; Zhao, S.R.; Mai, S.; Cepko, C.L. AAV cis-regulatory sequences are correlated with ocular toxicity. Proc. Natl. Acad. Sci. USA 2019, 116, 5785-5794. [CrossRef] [PubMed]

114. Claudio, L.; Martiney, J.A.; Brosnan, C.F. Ultrastructural studies of the blood-retina barrier after exposure to interleukin-1 beta or tumor necrosis factor-alpha. Lab. Investig. 1994, 70, 850-861. [PubMed]

115. Bamforth, S.D.; Lightman, S.; Greenwood, J. The effect of TNF-alpha and IL-6 on the permeability of the rat blood-retinal barrier in vivo. Acta Neuropathol. 1996, 91, 624-632. [CrossRef]

116. Aveleira, C.A.; Lin, C.M.; Abcouwer, S.F.; Ambrósio, A.F.; Antonetti, D.A. TNF- $\alpha$ signals through PKC乙/NF- $\mathrm{B} B$ to alter the tight junction complex and increase retinal endothelial cell permeability. Diabetes 2010, 59, 2872-2882. [CrossRef]

117. Olson, J.K.; Miller, S.D. Microglia initiate central nervous system innate and adaptive immune responses through multiple TLRs. J. Immunol. 2004, 173, 3916-3924. [CrossRef]

118. Reinert, L.S.; Lopušná, K.; Winther, H.; Sun, C.; Thomsen, M.K.; Nandakumar, R.; Mogensen, T.H.; Meyer, M.; Vægter, C.; Nyengaard, J.R.; et al. Sensing of HSV-1 by the cGAS-STING pathway in microglia orchestrates antiviral defence in the CNS. Nat. Commun. 2016, 7, 13348. [CrossRef]

119. Li, L.; Eter, N.; Heiduschka, P. The microglia in healthy and diseased retina. Exp. Eye Res. 2015, 136, $116-130$. [CrossRef]

120. Amado, D.; Mingozzi, F.; Hui, D.; Bennicelli, J.L.; Wei, Z.; Chen, Y.; Bote, E.; Grant, R.L.; Golden, J.A.; Narfstrom, K.; et al. Safety and efficacy of subretinal readministration of a viral vector in large animals to treat congenital blindness. Sci. Transl. Med. 2010, 2, 21ra16. [CrossRef]

121. Bennett, J.; Wellman, J.; Marshall, K.A.; McCague, S.; Ashtari, M.; DiStefano-Pappas, J.; Elci, O.U.; Chung, D.C.; Sun, J.; Wright, J.F.; et al. Safety and durability of effect of contralateral-eye administration of AAV2 gene therapy in patients with childhood-onset blindness caused by RPE65 mutations: A follow-on phase 1 trial. Lancet 2016, 388, 661-672. [CrossRef] 
122. Reichel, F.F.; Peters, T.; Wilhelm, B.; Biel, M.; Ueffing, M.; Wissinger, B.; Bartz-Schmidt, K.U.; Klein, R.; Michalakis, S.; Fischer, M.D.; et al. Humoral Immune Response After Intravitreal But Not After Subretinal AAV8 in Primates and Patients. Investig. Ophthalmol. Vis. Sci. 2018, 59, 1910-1915. [CrossRef] [PubMed]

123. Li, Q.; Miller, R.; Han, P.Y.; Pang, J.; Dinculescu, A.; Chiodo, V.; Hauswirth, W.W. Intraocular route of AAV2 vector administration defines humoral immune response and therapeutic potential. Mol. Vis. 2008, 14, 1760-1769.

124. Seitz, I.P.; Michalakis, S.; Wilhelm, B.; Reichel, F.F.; Ochakovski, G.A.; Zrenner, E.; Ueffing, M.; Biel, M.; Wissinger, B.; Bartz-Schmidt, K.U.; et al. Superior Retinal Gene Transfer and Biodistribution Profile of Subretinal Versus Intravitreal Delivery of AAV8 in Nonhuman Primates. Invest. Ophthalmol. Vis. Sci. 2017, 58, 5792-5801. [CrossRef] [PubMed]

125. Leborgne, C.; Barbon, E.; Alexander, J.M.; Hanby, H.; Delignat, S.; Cohen, D.M.; Collaud, F.; Muraleetharan, S.; Lupo, D.; Silverberg, J.; et al. IgG-cleaving endopeptidase enables in vivo gene therapy in the presence of anti-AAV neutralizing antibodies. Nat. Med. 2020, 7. [CrossRef]

126. Heier, J.S.; Kherani, S.; Desai, S.; Dugel, P.; Kaushal, S.; Cheng, S.H.; Delacono, C.; Purvis, A.; Richards, S.; Le-Halpere, A.; et al. Intravitreous injection of AAV2-sFLT01 in patients with advanced neovascular age-related macular degeneration: A phase 1, open-label trial. Lancet 2017, 390, 50-61. [CrossRef]

127. Kotterman, M.A.; Yin, L.; Strazzeri, J.M.; Flannery, J.G.; Merigan, W.H.; Schaffer, D.V. Antibody neutralization poses a barrier to intravitreal adeno-associated viral vector gene delivery to non-human primates. Gene Ther. 2015, 22, 116-126. [CrossRef]

128. Rhen, T.; Cidlowski, J.A. Antiinflammatory action of glucocorticoids-new mechanisms for old drugs. N. Engl. J. Med. 2005, 353, 1711-1723. [CrossRef] [PubMed]

129. Hobbs, H.E.; Sorsby, A.; Freedman, A. Retinopathy following chloroquine therapy. Lancet 1959, 2, $478-480$. [CrossRef]

130. Mavrikakis, I.; Sfikakis, P.P.; Mavrikakis, E.; Rougas, K.; Nikolaou, A.; Kostopoulos, C.; Mavrikakis, M. The incidence of irreversible retinal toxicity in patients treated with hydroxychloroquine: A reappraisal. Ophthalmology 2003, 110, 1321-1326. [CrossRef]

131. Rynes, R.I. Ophthalmologic safety of long-term hydroxychloroquine sulfate treatment. Am. J. Med. 1983, 75, 35-39. [CrossRef]

132. Yusuf, I.H.; Sharma, S.; Luqmani, R.; Downes, S.M. Hydroxychloroquine retinopathy. Eye 2017, 31, 828-845. [CrossRef]

133. Melles, R.B.; Marmor, M.F. The risk of toxic retinopathy in patients on long-term hydroxychloroquine therapy. JAMA Ophthalmol. 2014, 132, 1453-1460. [CrossRef] [PubMed]

134. Fanouriakis, A.; Kostopoulou, M.; Alunno, A.; Aringer, M.; Bajema, I.; Boletis, J.N.; Cervera, R.; Doria, A.; Gordon, C.; Govoni, M.; et al. 2019 update of the EULAR recommendations for the management of systemic lupus erythematosus. Ann. Rheum. Dis. 2019, 78, 736-745. [CrossRef] [PubMed]

135. Yusuf, I.H.; Foot, B.; Galloway, J.; Ardern-Jones, M.R.; Watson, S.L.; Yelf, C.; Burdon, M.A.; Bishop, P.N.; Lotery, A.J. The Royal College of Ophthalmologists recommendations on screening for hydroxychloroquine and chloroquine users in the United Kingdom: Executive summary. Eye 2018, 32, 1168-1173. [CrossRef]

136. Marmor, M.F.; Kellner, U.; Lai, T.Y.; Melles, R.B.; Mieler, W.F. Recommendations on Screening for Chloroquine and Hydroxychloroquine Retinopathy (2016 Revision). Ophthalmology 2016, 123, 1386-1394. [CrossRef] [PubMed]

137. Leung, L.S.; Neal, J.W.; Wakelee, H.A.; Sequist, L.V.; Marmor, M.F. Rapid Onset of Retinal Toxicity from High-Dose Hydroxychloroquine Given for Cancer Therapy. Am. J. Ophthalmol. 2015, 160, 799-805. [CrossRef]

138. Marmor, M.F. COVID-19 and Chloroquine/Hydroxychloroquine: Is there Ophthalmological Concern? Am. J. Ophthalmol. 2020, 213, A3-A4. [CrossRef]

139. Tett, S.E.; Cutler, D.J.; Day, R.O.; Brown, K.F. Bioavailability of hydroxychloroquine tablets in healthy volunteers. Br. J. Clin. Pharmacol. 1989, 27, 771-779. [CrossRef]

140. Jallouli, M.; Galicier, L.; Zahr, N.; Aumaitre, O.; Frances, C.; Le Guern, V.; Liote, F.; Smail, A.; Limal, N.; Perard, L.; et al. Determinants of hydroxychloroquine blood concentration variations in systemic lupus erythematosus. Arthritis Rheumatol. 2015, 67, 2176-2184. [CrossRef]

141. Wainer, I.W.; Chen, J.C.; Parenteau, H.; Abdullah, S.; Ducharme, J.; Fieger, H.; Iredale, J. Distribution of the enantiomers of hydroxychloroquine and its metabolites in ocular tissues of the rabbit after oral administration of racemic-hydroxychloroquine. Chirality 1994, 6, 347-354. [CrossRef] 
142. Li, C.; He, Y.; Nicolson, S.; Hirsch, M.; Weinberg, M.S.; Zhang, P.; Kafri, T.; Samulski, R.J. Adeno-associated virus capsid antigen presentation is dependent on endosomal escape. J. Clin. Investig. 2013, 123, 1390-1401. [CrossRef] [PubMed]

143. Satoh, N.; Abe, T.; Nakajima, A.; Sakuragi, S. Recurrent varicella-zoster virus retinitis in a patient treated with systemic corticosteroids. Ocul. Immunol. Inflamm. 1998, 6, 185-188. [CrossRef]

144. Benz, M.S.; Glaser, J.S.; Davis, J.L. Progressive outer retinal necrosis in immunocompetent patients treated initially for optic neuropathy with systemic corticosteroids. Am. J. Ophthalmol. 2003, 135, 551-553. [CrossRef]

145. Han, J.M.; Ahn, J.; Park, K.H.; Woo, S.J. Presumed necrotizing viral retinitis after intravitreal triamcinolone injection: Case report. Korean J. Ophthalmol.: KJO 2011, 25, 451-454. [CrossRef] [PubMed]

146. Takakura, A.; Tessler, H.H.; Goldstein, D.A.; Guex-Crosier, Y.; Chan, C.C.; Brown, D.M.; Thorne, J.E.; Wang, R.; Cunningham, E.T., Jr. Viral retinitis following intraocular or periocular corticosteroid administration: A case series and comprehensive review of the literature. Ocul. Immunol. Inflamm. 2014, 22, 175-182. [CrossRef] [PubMed]

(C) 2020 by the authors. Licensee MDPI, Basel, Switzerland. This article is an open access article distributed under the terms and conditions of the Creative Commons Attribution (CC BY) license (http://creativecommons.org/licenses/by/4.0/). 